Summer 2015

\title{
Legislating Safety Nets: Comparing Recent Social Protection Laws in Asia
}

Surabhi Chopra Prof.

Chinese University of Hong Kong, surabhic@cuhk.edu.hk

Follow this and additional works at: https://www.repository.law.indiana.edu/ijgls

Part of the International Law Commons, Legislation Commons, and the Social Welfare Law Commons

\section{Recommended Citation}

Chopra, Surabhi Prof. (2015) "Legislating Safety Nets: Comparing Recent Social Protection Laws in Asia," Indiana Journal of Global Legal Studies: Vol. 22 : Iss. 2 , Article 10.

Available at: https://www.repository.law.indiana.edu/ijgls/vol22/iss2/10

This Symposium is brought to you for free and open access by the Law School Journals at Digital Repository @ Maurer Law. It has been accepted for inclusion in Indiana Journal of Global Legal Studies by an authorized editor of Digital Repository @ Maurer Law. For more information, please contact rvaughan@indiana.edu.

\section{$\Psi$}

JEROME HALL LAW LIBRARY

INDIANA UNIVERSITY

Maurer School of Law
Bloomington 


\title{
Legislating Safety Nets: Comparing Recent Social Protection Laws in Asia
}

\author{
SURABHI CHOPRA*
}

ABSTRACT

In recent years, several Asian countries have begun moving away from patchwork welfare programs toward providing more comprehensive social protection. This is a significant shift in a region where social welfare has not been politically popular, and the family has traditionally absorbed the burden of supporting the young, the old, and the ailing. Two of these states-India and Indonesia-have put new social protection initiatives into law rather than simply formulating executive policy. In this article, I examine recent social protection laws in both countries. I look in particular at India's National Food Security Law, passed in 2013, and Indonesia's laws on the National Social Security System, passed in 2004 and 2011. These laws deserve attention because they aim not just to extend benefits, but also to advance economic and social rights, which are recognized in both India and Indonesia at the constitutional level. Thus, these recent social protection laws potentially deepen what Brinks and Gauri describe as the "legalization" of welfare policy, whereby legal rights assume importance in policy, and legal professionals, judges in particular, become significant in implementing them. As such, these laws are likely to, and arguably should, impose quite hard-edged obligations on the government and enable individuals to hold the government to its obligations. At the same time, recent social protection laws have the potential to allay concerns that legal enforcement of economic social rights distorts policy and dilutes the separation of powers. Through my analysis, I show that social protection laws in both India and Indonesia have primarily expanded the policies

* Assistant Professor, Faculty of Law, Chinese University of Hong Kong. I presented an early draft of this article at the Annual Symposium of the Indiana Journal of Global Legal Studies on "Law and the Globalization of Austerity" (Indiana University Maurer School of Law, September 10-12, 2014), and am grateful for the feedback I received from my co-participants at the symposium. I am also grateful to the Chinese University of Hong Kong for supporting my research through a Direct Research Grant.

Indiana Journal of Global Legal Studies Vol. 22 \#2 (Summer 2015)

(C) Indiana University Maurer School of Law 
that preceded them, rather than fundamentally restructured how particular forms of social protection are delivered. Further, none of these laws define the socioeconomic rights underlying them in a detailed, substantive manner, creating rights that are minimal and definite, or broad but weak. I go on to argue that despite gaps, flaws, and missed opportunities, these laws-with the sum of rights, remedies, and accountability mechanisms they contain-have made the rights to food and social security more stable, and are likely to make them more accessible to individuals.

\section{INTRODUCTION}

In recent years, several Asian countries have begun moving away from patchwork welfare programs toward providing more comprehensive social protection. ${ }^{1}$ This shift is significant in a region where social welfare has not been politically popular, and where the family has traditionally absorbed the burden of supporting the young, the old, and the ailing. ${ }^{2}$ While many European governments have whittled down welfare measures after the global financial crisis in the late 2000s, Asian governments are, it appears, expanding social protection and trying to tackle deprivation with fresh seriousness.

Two of these states-India and Indonesia-have put new social protection initiatives into law, rather than simply formulating executive policy. In this article, I examine recent social protection laws in both countries. I look in particular at India's National Food Security Law, passed in 2013, and Indonesia's laws on the National Social Security System, passed in 2004 and 2011. These laws are significant not simply because they facilitate the implementation of complex social policies. Of course, the policies contained in recent legislation involve difficult, often controversial, choices about how social protection should be designed, whom to cover, and how to reach beneficiaries-all of which are worthy of scrutiny. Those laws also deserve attention because they aim not just to extend benefits, but also to advance economic and social rights, which are recognized in India and Indonesia at the constitutional level.

In both constitutional orders, citizens are entitled to certain basic goods and services as a matter of right, and the state is, correspondingly, obligated to protect economic and social rights. Those justiciable social and economic rights have been the bases for judicial review of government policies and practice. Such judicial review divides

1. See Asian Welfare States: New Cradles to Graves, Economist, Sept. 8, 2012, available at $\mathrm{http}: / / \mathrm{www} . e c o n o m i s t . c o m / n o d e / 21562210 \#$ sthash.' DXW0JUxf.dpbs.

2. See Ian Holliday, Productivist Welfare Capitalism: Social Policy in East Asia, 48 POL. STUD. 706, 709, 714-15 (2000). 
scholarly opinion, as does the justiciability of socioeconomic rights and, even more fundamentally, those rights' very existence. Staunch critics of social and economic rights claim that essential goods and services are not rights at all. More moderate skeptics argue that while socioeconomic rights might be conceptually defensible, these rights should not be justiciable, given the hazards of judicial review, including its potentially significant budgetary implications. Those objections could be dismissed as irrelevant, given that an increasing number of states recognize social and economic rights in their constitutions. ${ }^{3}$ However, the trajectory of judicial attempts to enforce those rights indicates that the skeptics' apprehensions have not been easy to address.

Recent social protection laws in India and Indonesia mark a new stage in the debate on whether and how social and economic rights can be implemented. This legislation potentially deepens what Brinks and Gauri describe as the "legalization" of welfare policy, whereby legal rights, as well as other legal concepts, assume importance in designing policy, and legal professionals-judges in particular-become significant in implementing it. ${ }^{4}$ As such, these laws are likely to, and arguably should, impose quite hard-edged obligations on the government and enable individuals to hold the government to its obligations. At the same time, recent social protection laws have the potential to allay concerns that legal enforcement of economic social rights distorts policy and dilutes the separation of powers.

With those concerns in mind, I analyze the recent Indian law on food security and Indonesian laws on social security. There is considerable research on judicial review of social and economic rights, and there is a vast body of work by economists and policy experts on food, social security, and poverty reduction policies. However, there is relatively little academic reflection on legislating, rather than litigating, social and economic rights. Comparative legal research on Asia is similarly quite limited. 5 The laws I look at here contain measures that

3. See Courtney Jung, Ran Hirschl \& Evan Rosevear, Economic and Social Rights in National Constitutions, 62 AM. J. CoMP. L. 1043, 1050-51 (2014).

4. See VARUN GAURI \& DANIEL M. BRINKS, Introduction: The Elements of Legalization and the Triangular Shape of Social and Economic Rights, in CouRTING SOCLAL JUSTICE: Judicial ENForCEMENT OF SOCIAL AND ECONOMIC RightS IN THE DEVELOPING WoRld 1, 3 (Varun Gauri \& Daniel M. Brinks eds., 2010); Varun Gauri \& DaniEl M. BrinKS, $A$ New Policy Landscape: Legalizing Social and Economic Rights in the Developing World in COURTING SOCIAL JUSTICE: JUDICIAL ENFORCEMENT OF SOCIAL AND ECONOMIC RightS IN THE Developing World at 303, 304, 334 (Varun Gauri \& Daniel M. Brinks eds., 2010).

5. For a recent example of comparative legal research focusing on Asia, see generally Comparative Constitutional LaW IN ASIa (Rosalind Dixon \& Tom Ginsburg eds., 2014) 
potentially affect the health and well-being of millions of people, and appraising those important endeavors specifically from a legal perspective might be instructive. In the rest of this article, I evaluate how these laws formulate the citizens' entitlements and the state's corresponding obligations, what remedies they provide, and what measures they include to foster accountability. I consider how they grapple with the underlying rights to food and social security respectively, while accommodating the challenges-financial, practical, and political-of implementing policies in large, diverse countries with high levels of inequality.

In Section I of this article, I point out that social and economic rights have received constitutional recognition and have been considered amenable to individual enforcement only quite recently. I discuss the debate around judicial review of these rights and argue that legislation protecting social and economic rights would make these rights more stable and accessible to individuals, while addressing the concerns raised by judicial review. In Section II, I discuss the political, legal, and economic differences that complicate comparing an Indian law to an Indonesian law, but I argue that there are sufficient socioeconomic similarities to make comparative analysis of social protection laws in these large, rapidly developing Asian countries viable as well as important. In Section III, I analyze India's recent National Food Security Act, situating the law in its constitutional and policy context. In Section IV, I similarly analyze Indonesia's social security laws. In Section V, I reflect on both states' laws. I point out that social protection laws in India and Indonesia are primarily expanding the policies that preceded them, rather than fundamentally restructuring how particular forms of social protection are delivered. Further, none of these laws define the socioeconomic rights underlying them in a detailed, substantive manner-creating rights that are either narrow and strong, or broad but weak. I go on to argue that despite gaps, flaws, and missed opportunities, these laws - with the sum of rights, remedies, and accountability mechanisms they contain-have made the rights to food and social security more stable, and are likely to make food and social security more accessible to individuals.

(examining constitutional issues across Asian jurisdictions including freedom of religion, constitutional courts, and property rights). 


\section{ENFORCING ECONOMIC AND SOCIAL RIGHTS}

\section{A. Gaining Equal Recognition}

All three laws examined in this article engage social and economic rights-in particular, the rights to food, healthcare, and social security. Such rights are sometimes described as "second generation" rights, and treated as distinct from so-called "first generation" civil and political rights, such as the rights to privacy or a fair trial. The (non-binding) Universal Declaration of Human Rights ${ }^{6}$ does not divide rights into two categories. However, international treaties that followed in the wake of the Universal Declaration of Human Rights divide the list of rights in the Declaration, with the International Covenant on Civil and Political Rights $^{7}$ (ICCPR) recognizing rights related to political participation and personal autonomy, and the International Covenant on Economic, Social and Cultural Rights ${ }^{8}$ (ICESCR) recognizing rights to essential goods and services. This bifurcation resulted in part from normative disagreement and in part from Cold War politics. ${ }^{9}$ Some Western governments followed the example of the United States at the time and did not recognize economic and social rights. ${ }^{10}$ At the time the Covenants were drafted, and through the next two decades, economic and social rights were viewed as imposing unfeasible burdens on the state, and were contrasted with civil and political rights, which were viewed as requiring only restraint by the state, rather than outlay. ${ }^{11}$

6. See Universal Declaration of Human Rights, G.A. Res. 217 (III) A, U.N. Doc. A/RES/217(III), at 71 (Dec. 10, 1948).

7. See, e.g., International Covenant on Civil and Political Rights, G.A. Res. 2200A (XXI), 21 U.N. GAOR, Supp. No. 16, U.N. Doc. A/6316, at 52 (entered into force Mar. 23, 1976) (stating that people have political and civil rights, as well as cultural and social rights).

8. See International Covenant on Economic, Social and Cultural Rights, G.A. Res. 2200A (XXI), 21 U.N. GAOR, Supp. No. 16, U.N. Doc. A/6316, at 49 (entered into force Jan. 3, 1976) [hereinafter ICESCR].

9. See Philip Alston \& Ryan Goodman, International Human Rights 278-81, 292 (2013). United Nations human rights conventions applicable to particular groups do not divide rights into two families or generations. See Convention on the Elimination of All Forms of Discrimination Against Women, G.A. Res. 34/180, 34 U.N. GAOR, Supp. No. 46, U.N. Doc. A/34/46, at 193 (Sept. 3, 1981); Convention on the Rights of the Child, G.A. Res. 44/25, Annex, 44 U.N. GAOR, Supp. No. 49, U.N. Doc. A/44/49, at 167 (Sept. 2, 1990).

10. The United States signed the ICESCR in 1977, but has yet to ratify it. See International Covenant on Economic, Social and Cultural Rights, G.A. Res. 2200A (XXI), 21 U.N. GAOR, Supp. No. 16, U.N. Doc. A/6316 (Jan. 3, 1976). For updated ratification information see the online updated version of Chapter IV Human Rights: ICESCR, U.N. TREATY COLLECTION, https://treaties.un.org/pages/viewdetails.aspx?chapter=4\&lang=en\& mtdsg_no=iv.3\&src=treaty (last visited Jan. 15, 2015).

11. See ALSTON \& GOODMAN, supra note 9, at 277. 
Many human rights lawyers have criticized this position, pointing out that international law imposes multilayered duties on states in relation to any human right. United Nations expert bodies on both the ICCPR and the ICESCR have repeatedly clarified that states are obligated to respect rights - that is, to refrain from violating human rights-and to protect rights-that is, to prevent violations by third parties. ${ }^{12}$ Thus, states have "negative" obligations that require restraint, as well as "positive" obligations that require financial and practical effort whether dealing with rights to education or shelter, or dealing with rights such as freedom of speech that are found in some of the oldest liberaldemocratic national constitutions.

The current position in international human rights law is that both sets of rights are "interrelated, interdependent and indivisible." 13 Civil and political rights play an important role in securing basic goods and services. Individuals who are able to criticize political leaders, examine their performance, protest, and form associations to lobby the state are better able to draw attention to their own material needs than their counterparts who lack those freedoms. Sen and Drèze argue that rulers who are judged daily by the media and periodically at the ballot box move quickly to ameliorate extreme deprivation. They highlight the fact that no democratic government has allowed a drought to escalate into a famine. ${ }^{14}$ In contrast, Sen and Drèze point to famines in colonial India and the famine resulting from Chairman Mao's Great Leap Forward policy in China as preventable disasters caused by the neglect of undemocratic, unaccountable governments. ${ }^{15}$

Just as civil and political rights strengthen access to basic necessities, economic and social rights facilitate political participation and personal autonomy. A person who does not have secure access to food, healthcare, or housing faces a heightened risk of violence and arbitrary treatment from state actors. ${ }^{16}$ Poverty weakens the wherewithal to participate in public life and pursue private goals and enjoyment-the slum dweller forced to pay protection money will very likely lack the resources to complain to the police and demand redress,

12. See id. at 292; Aryeh Neir, Social and Economic Rights: A Critique, in ALSTON \& GoODMAN, supra note 9, at 297-99.

13. See What are human rights?, UNITED NATIONS HuMAN Rights OFFICE, http://www. ohchr.org/EN/Issues/Pages/WhatareHumanRights.aspx, (last updated 2015); See also, Comm. on Economic, Social and Cultural Rights, General Comment 12, Right to Adequate Food on its 20th Sess., 1999, U.N. Doc. E/C.12/1999/5 (1999); See Christine Chinkin, The United Nations Decade for the Elimination of Poverty: What Role for International Law?, 54 CURRENT LEGAL PROBS. 553, 576-80 (2001) (discussing different levels of obligation).

14. See JEAN DREze \& AMARTYA Sen, Hunger AND Public ACTION 263 (1989).

15. See id. at $8,212-13$.

16. See Chinkin, supra note 13 , at 554-56, 560-61. 
and a woman who must devote several hours a day to collect water will have little time to attend the meetings of the village council. Chinkin characterizes poverty as "in itself a denial of fundamental human rights and a barrier to the enjoyment of all other human rights." 17

This understanding, which accords equal priority to economic and social rights, seems morally intuitive, particularly once we acknowledge that civil and political rights impose burdens on the state-as training the police, organizing free and fair elections, and regulating hate speech clearly do. Accepting that individuals have the rights to freedom of expression or a fair trial by virtue of being human, or to be residents within particular national boundaries, it is difficult to deny that individuals also have rights to the food, water, and shelter that are essential for survival and to the healthcare and education that are necessary for a safe, autonomous existence. ${ }^{18}$ To argue otherwise betrays a thin conception of dignity and a naïve conception of politics.

The intertwined, mutually reinforcing nature of different rights is recognized by U.N. human rights bodies, human rights NGOs, and large sections of the international development community. This shift is reflected at the national level, too. The constitutions of 158 states recognize one or more economic and social rights as fundamental rights. ${ }^{19}$ However, constitutional recognition has been gradual-postcolonial constitutions drafted during the wave of decolonization after the Second World War tended not to recognize those rights. For example, the Indian Constitution recognized only civil and political rights when it came into force in 1950, but it included non-binding "Directive Principles of State Policy" that urge the executive branch to prioritize socioeconomic welfare. ${ }^{20}$ More recent constitutions, drafted during democratic transitions in several countries in the 1990s and 2000 s, have tended to include economic and social rights on the same footing as civil and political rights. ${ }^{21}$ Equal constitutional recognition

17. See id. at 556 .

18. See Amartya Sen, The Idea of Justice, in ALSTON \& GoOdMAN, supra note 9, at 305-06; See also James W. Nickel, Poverty and Rights, 55 PHIL. Q. 385, 393 (2005).

19. See Jung, Hirschl \& Rosevear, supra note 3 , at 6 .

20. INDIA CONST. arts. 36-51 (outlining many of the social and economic rights guaranteed to the Indian people by their constitution). The post-colonial constitutions of Sri Lanka, Bangladesh, Nepal, Pakistan also include aspirational Directive Principles of State Policy. See Iain Byrne \& Sara Hossain, South Asia: Economic and Social Rights Case Law of Bangladesh, Nepal, Pakistan, and Sri Lanka, in Social RIGHTS JURISPRUDENCE: EMERGING TRENDS IN INTERNATIONAL AND COMPARATIVE LAW 125, 12526 (Malcolm Langford ed., 2008).

21. See ALSTON \& GoODMAN, supra note 9, at 338-39, 353-55. Constitutional recognition of social and economic rights in Eastern Europe and Latin America in the 1990s elicited skepticism at the time. See MARK V. TUSHNET, WEAK COURTS, Strong 
renders these rights, at least in principle, justiciable and enforceable on similar terms to their civil and political counterparts.

\section{B. Enforcing Social and Economic Rights}

\section{Social and Economic Rights in the Courtroom}

Constitutional recognition of social and economic rights yielded attempts to enforce these rights in court in many states. In several developing countries, including, inter alia, India, South Africa, Bangladesh, Brazil, Nigeria, and Indonesia, individuals have challenged government acts as well as policies on the ground that the state is transgressing their socioeconomic rights. The resulting judicial review has caused consternation. ${ }^{22}$ Skeptics have cautioned that judges lack the necessary knowledge and technical expertise to review matters of public policy and do not have executives' bird's-eye appreciation of how a particular decision or program fits within the larger policy landscape. Therefore, judicial review of socioeconomic policy could result in decisions that burden the public exchequer, distort policy priorities, exceed what the state can deliver, damage macroeconomic outcomes, and diminish microeconomic efficiency.

In response to these criticisms, it has been argued that adjudicating a challenge to socioeconomic policy does not mean ousting the policy makers. ${ }^{23}$ On the contrary, defenders of judicial review argue, judges are well placed to hear such challenges. In constitutional democracies that allow judicial review, judges are experienced at elucidating constitutional standards and evaluating arguments and evidence against those standards. Moreover, judges are political actors-sensitive to public opinion and concerned about credibility-and are therefore unlikely to ignore budgetary constraints or to dictate the details of socioeconomic policy. ${ }^{24}$

Courts in many states have conducted judicial review based on socioeconomic rights, so it might seem as if skepticism about such review were ill founded. The landmark cases from different jurisdictions

RightS: JUDICIAL REVIEW AND SOCIAL WELFARE RIGHTS IN COMPARATIVE CONSTITUTIONAL LAW 233-37 (2008).

22. For a review of this debate, see Marius Pieterse, Coming to Terms with Judicial Enforcement of Socio-Economic Rights, 20 S. AFR. J. HUM. RTS. 383, 391-392 (2004).

23. See, e.g., id. at 391-399. For a personal perspective by a Justice of the Constitutional Court of South Africa on adjudicating claims based on social and economic rights, see Albie Sachs, Enforcement of Social and Economic Rights, 22 AM. U. INT'L L. REV., 673, 697-700.

24. See GAURI \& BRINKS, supra note 4 , at 3-4, 343-44. 
certainly show that courts have been more agile when adjudicating socioeconomic rights than their critics thought possible. However, this comparative jurisprudence also indicates that courts have been constrained by expertise and capacity, and, notwithstanding some ostentatious rhetoric, have tended to be quite timid when enforcing socioeconomic rights.

Many cases involve government failure to implement a policy, and courts have pushed governments to follow through on their preexisting plans and intentions. In cases that reveal a policy vacuum, courts have directed governments, in relatively general terms, to move to a particular end-as in the Grootbroom case where the South African Constitutional Court required the government to implement a housing policy for poor slum residents whose homes were being razed. ${ }^{25}$ However, in other cases, courts have ordered a far more specific outcome, such as expanding a program providing school lunches to primary schools throughout India ${ }^{26}$ and supplying anti-retroviral drugs to HIV-positive pregnant women in health centers throughout South Africa rather than only in a few select facilities. ${ }^{27}$ It is worth noting, though, that cases in this latter category are rare. Even in decisions such as Treatment Action Campaign on access to anti-retroviral drugs in South Africa or People's Union of Civil Liberties on provision of school lunches in India, courts have expanded existing government programs rather than created new ones. Moreover, courts have tended to ask, expressly or impliedly, whether it is reasonable to withhold particular goods or services from vulnerable individuals or groups, rather than applying a more exacting standard or elucidating what the socioeconomic right at issue requires the state to deliver. ${ }^{28}$

Thus, courts have pushed governments to improve particular instances of inertia or neglect, but judicial intervention has neither yielded generally applicable standards nor clarified the state's obligations. International law is more forthcoming on standards and legal obligations in relation to economic and social rights. The ICESCR acknowledges the vast variation in wealth, poverty, and state capacity across different countries, and therefore, requires states to take steps "with a view to achieving progressively the full realization of the rights recognized" in the Covenant. ${ }^{29}$ In 1990, the U.N. Committee on

25. See ALSTON \& GOODMAN, supra note 9 , at 363.

26. See my later discussion of the Indian Supreme Court's orders in PUCL vs. Union of India and Others, Writ Petition [Civil] 196 of 2001, infra Part IV; see also ALSTON \& GOODMAN, supra note 9, at 352-53.

27. See ALSTON \& GOODMAN, supra note 9, at 363-369.

28. See Pieterse, supra note 22, at 407-16.

29. ICESCR, supra note 8 , art. 2, १ 1 . 
Economic, Social, and Cultural Rights (CESCR) emphasized that the "progressive realization" obligation, as it is called, is not a euphemism freeing states from concrete responsibilities. ${ }^{30}$ States are obligated, the Committee clarified, to "move as expeditiously and effectively as possible" toward securing social and economic rights for individuals. ${ }^{31}$ Further, in relation to each right, states have a current rather than longer-term obligation to provide "minimum essential levels of each of the rights." 32 The "minimum core" obligation parallels the "immediate obligation to respect and ensure" rights in the ICCPR. ${ }^{33}$

National jurisprudence has not deployed this international guidance. Judicial decisions that require a particular service to be delivered could be understood as impliedly including that service in the state's minimum, immediately effective obligations. However, courts have not engaged with the concept of the minimum core or sought to define it. Judicial reticence in this regard has been criticized by some commentators. ${ }^{34}$ Others, including Tushnet ${ }^{35}$ and Dixon, ${ }^{36}$ are more sanguine. Dixon suggests that courts should alleviate the democratic deficit created by justiciable economic and social rights by recognizing weak rights (e.g., applying a deferential standard of review or leaving the state's obligations nebulous) or granting weak remedies (e.g., requiring a rights violation to be addressed but leaving method and timing to the executive branch) when dealing with positive obligations imposed by these rights. ${ }^{37}$

30. Comm. on Economic, Social and Cultural Rights (CESCR), General Comment 3, The Nature of States Parties' Obligations (art. 2, para. 1, of the Covenant), 5th Sess., Dec. 14, 1990, U.N. Doc E/1991/23, at 9 (Jan. 1, 1991) Thereinafter CESCR General Comment 3].

31. CESCR General Comment 3 at 99.

32. Id. at $\uparrow 10$.

33. Cf. id. at I 9 (contrasting the general "progressive realization" standard of the ICESCR with the ICCPR).

34. See David BIlChitz, Poverty and Fundamental Rights: The Justification and ENFORCEMENT OF SOCIO-ECONOMIC RIGHTS 135-77 (2007); Pieterse, supra note 22, at 407 (criticizing the South African Constitutional Court for its failure to define a minimum core in Grootboom).

35. See TUSHNET, supra note 21, at 243-44, 247-50 (noting that the South African Constitutional Court's rejection of "minimum core" in Grootboom was not a rejection of justiciable socio-economic rights altogether and suggesting a difference between "weak" and "strong" remedies for violations of rights).

36. See Rosalind Dixon, Creating Dialogue About Socioeconomic Rights: Strong-form Versus Weak-form Judicial Review Revisited, 5 INT'L J. CoNST. L. 391, 409-413 (2007) (recognizing the trade-offs inherent in judicial review of positive rights).

37. See id. at 409-13. In the case of South Africa, Dixon argues for courts, when recognizing weak social and economic rights, to apply stronger remedies to protect those rights. 
As discussed earlier, justiciable social and economic rights are relatively recent, as are the resulting litigation and judicial responses to these rights. About two decades of experience across different jurisdictions indicates that fears about the "judicialization" of socioeconomic policy are misplaced, but also that the judicial role is, perhaps unavoidably, narrow and reactive. Essentially modest decisions by courts have generated few broadly applicable principles. When courts have granted ambitious, large-scale remedies, they have struggled to monitor government compliance. Courts have developed innovative mechanisms-such as appointing experts, holding periodic hearings to check on progress, or directing the national human rights institution to monitor implementation-to track government compliance with judicial directives. Despite such innovations, judges have struggled to accurately assess compliance, and governments have often evaded or neglected court orders. ${ }^{38}$

\section{Legislating Social and Economic Rights}

Thus, while the status of socioeconomic rights as legitimate legal entitlements is fairly settled, the scope and enforceability of these rights remains moot. These issues could be tackled through legislation. Laws recognizing and protecting socioeconomic rights could address the concerns about legitimacy raised by judicial review. Once a law passes with majority support in the legislature, its representativeness, at least in a formal sense, is in little doubt. During litigation, a small set of actors air their arguments, even accounting for submissions by experts such as amicus curiae. Legislative debate over a draft law has the potential to elicit broader civil society engagement, through individual legislators, committees in the legislature, or public consultation. Law making is likely to be more participatory not only as compared to litigation, but also as compared to executive policy making.

The ICESCR requires states to take "all appropriate means, including particularly the adoption of legislative measures" 39 to advance the rights in the Covenant. The ICESCR has reminded states that legislation should ideally include judicial remedies. ${ }^{40}$ More recently, some multilateral agencies and human rights experts have championed

38. For a discussion of the difficulties in enforcing and monitoring compliance with court decisions, see Dixon, supra note 36, at 414-15; and for a summary of remedial innovation by Indian courts, see Christine M. Forster \& Vedna Jivan, Public Interest Litigation and Human Rights Implementation: The Indian and Australian Experience, 3 ASIAN J. COMP. L. 19-21 (2008).

39. ICESCR, supra note 8, art. 2, I 1.

40. CESCR General Comment 3, supra note 30, I 4-5. 
socioeconomic rights legislation. ${ }^{41}$ That said, there is still relatively little detailed guidance on drafting laws on socioeconomic rights. The Food and Agricultural Organization's handbook on legislating the right to food is one of the few guides on how to legislate these rights. ${ }^{42} \mathrm{It}$ emphasizes the importance of clarifying rights and duties, assigning duties to different levels of government, providing both administrative and judicial remedies, protecting the right to information, and building accountability mechanisms to guard against negligence and corruption. Clearly, states could pass legislation that primarily performs a functional, organizing role. But, legislation is also an apt vehicle for robustly recognizing an enforceable right and building the necessary framework to implement that right.

A law focusing on a socioeconomic right could particularize that right. Defining the full scope of a right is challenging, particularly as standards for socioeconomic rights are nowhere near as established as for civil and political rights, but even clarifying the minimum entitlements would be a valuable contribution. A law could also codify the state's responsibilities and articulate harder-edged obligations than are typically incorporated in policy documents. While a law should define the state's minimum core obligations, it could also pin down "progressive realization" targets-by establishing a system for setting targets, developing benchmarks, and monitoring progress. Similarly, a law can create mechanisms for cross-sectorial coordination as well as lines of accountability. It provides an opportunity to synthesize domestic practice and jurisprudence, as well as international standards and comparative benchmarks.

Importantly, a law that defines an individual's rights and the state's obligations will likely make it easier for individuals to challenge violations. Challenging government actions on the basis of a constitutional right requires specialized legal expertise and knowledge of existing jurisprudence. A constitutional challenge resting on a socioeconomic right is likely to be somewhat speculative and exploratory as rights-specific precedents and comparative examples are quite limited. Despite constitutional recognition, social and economic rights continue to be difficult to enforce. Ordinary law, with its relative

41. See, e.g, Comm. on Economic, Social and Cultural Rights (CESCR), General Comment 9, The Domestic Application of the Covenant, 19th Sess., U.N. Doc. E/C.12/1998/24, at If 6-8 (Dec. 1, 1998) [hereinafter CESCR General Comment 9]. See generally DUBRavka BoJic BULTRINI, GUIDE ON LEgISLATING FOR THE RIGHT TO FOOD 53182. (2009) (explaining the need and providing direction for framework laws regarding the right for food), available at http://www.fao.org/righttofood/publications/publicationsdetail/en/c/129278/ [hereinafter FAO Guide].

42. See FAO Guide, supra note 41. 
specificity, can provide the scaffolding that makes enforcement and accountability more accessible.

Greater accessibility is potentially fostered not just by the details of the law and the infrastructure it authorizes, but also by the fact of legislation. A law, emerging from a process of discussion and debate with the imprimatur of the legislature, is more likely to be viewed as important, perhaps even as symbolic, than policy alone. It could, therefore, serve as a tool for education and awareness, as shorthand for a particular set of entitlements.

In addition to being perceived as significant, a law focusing on a socioeconomic right is likely to provide firmer protection for the right than a policy would. Policies are easier to change, and therefore, more vulnerable to reversal when the government's priorities shift. Social protection measures represent bargains across social classes (when the poor receive support), across generations (when the elderly receive support), and across time (when individuals' present-day earnings contribute to eventual, future support). Unsurprisingly, social protection is often politically fraught and sometimes jettisoned by governments trying to distinguish themselves from the dispensation that preceded them. Of course, policies that are very popular are difficult to reverse, but legislation can serve as a faster way to entrench at least minimum protection for social and economic rights. Repealing or amending a law is more difficult than discarding or altering a policy. Thus, legislation can serve as a commitment device that constrains future policy makers and compels future legislators to debate and vote-in public, under media scrutiny -on repeal or amendment.

This "stickiness" matters in relation to social and economic entitlements, particularly for the poor in developing countries. Poverty entails high, persistent risk. ${ }^{43}$ A late monsoon or a drop in the world market price for rice can be ruinous for a subsistence farmer. The migrant contract worker in a third-world megacity can lose scarce work over a late train, a fractured arm, or a flare-up of asthma. The work that the poor do is itself often hazardous, and home provides little sanctuary as living conditions tend to be unhealthy and unsafe, particularly for women. ${ }^{44}$ Constantly navigating risk exacts a psychological, cognitive, and economic cost. 45 Economists have demonstrated that the poor try to spread or minimize risk through choices that, while understandable, are economically inefficient, such as running three small businesses rather than one or clinging to

43. See ABhiJIT V. Banerjee \& Esther Duflo, Poor ECONOMics: A Radical Rethinking of the Way to Fight Global Poverty 134-36 (2011).

44. See Chinkin, supra note 13, at 581-83.

45. See BANERJEE \& DUfLO, supra note 43 , at 140-41. 
traditional technology rather than trying something unfamiliar that would be more productive.46 Stable social protection that cannot be hastily altered would allow people living in poverty room to pursue beneficial choices that might otherwise seem too much of a material and emotional leap.

Thus, legislating social and economic rights potentially makes these rights more accessible and the corresponding obligations on the state firmer. Socioeconomic rights have had a protracted journey from public international law to constitutional recognition to judicial enforcement (in some states). Justiciability has posed genuine challenges and has met with mixed success. Legislation is the next stage in the legalization of social protection, and legislation has genuine benefits to offer alongside, but also distinct from, other efforts to secure essential goods and services as enforceable entitlements. While there is a wealth of economic and public policy research on welfare policies, there is relatively little doctrinal or socio-legal research on social protection laws. As such, the Indian and Indonesian laws I examine here deserve study. Of course, comparing Indian legislation with Indonesian laws raises the challenges common to most comparative research. The particular laws being compared have emerged from different legal traditions and distinct political contexts. These differences are germane, and I reflect on them below while also making the case for comparison.

\section{THE CASE FOR COMPARISON}

\section{A. Political Differences}

This article evaluates social protection laws that engage constitutional rights. In comparing these laws, I am aware of Bell's cautionary argument that public law is designed "as much in dialogue with the past as with the future" and is therefore, "particularly influenced by historical contingencies" and "anchored firmly in a national setting." 47 India and Indonesia have certainly had very different trajectories in the twentieth century. Indonesia is a unitary state with a presidential political system and a legislature produced by proportional representation. India is a parliamentary federation, albeit one where the balance of power lies with the central government. India has a common law legal system, a legacy of British colonial rule, while Indonesia has a hybrid pluralist legal system, combining civil law from

46. See id. at 141-43.

47. John Bell, Comparing Public Law, in Comparative LaW IN THE 21ST Century 235, 241 (Andrew Harding \& Esin Orücü eds., 2002). 
the Dutch colonial encounter with older, customary law, or adat, and some elements of Islamic law. ${ }^{48}$ Since India gained independence in 1947 , it has been a constitutional democracy with regular, periodic elections that have been reasonably free and fair. ${ }^{49}$ The Indian economy was heavily state controlled until the early 1990 s, when the government liberalized trade and capital markets. ${ }^{50}$ Indonesia, on the other hand, was an authoritarian state until 1998, when the Suharto regime fell in the wake of the Asian financial crisis of 1997-98. Indonesia's economy suffered more than that of any other Asian country during the crisis; its GDP fell by 13 percent in 1998.51 The crisis exposed the extent of plutocratic crony capitalism in Indonesia, with the public and private sectors organized in the service of the Suharto family and its allies..$^{52}$ The years following 1998, known as the reformasi era, saw deep political restructuring as Indonesia transitioned into a constitutional democracy. ${ }^{53}$ Thus, as compared to India, Indonesia is a far younger democracy. When analyzing laws, it is worth bearing in mind that the Indonesian legislature and judiciary were substantially controlled by the executive until 1998, ${ }^{54}$ and as a result, do not have a deep reserve of experience with independent law making and adjudication.

\section{B. Constitutional Recognition of Economic and Social Rights}

Contrasts in each country's political trajectory are significant when comparing legislation. It is also important to note that the laws being compared deal with different forms of social protection. Addressing widespread hunger in India and universalizing health insurance and

48. See Tim Lindsey \& Mas Achmad Santosa, The Trajectory of Law Reform in Indonesia: A Short Overview of Legal Systems and Change in Indonesia, in INDONESIA: LAW AND SOCIETY 3 (Tim Lindsey ed., 2008).

49. See Ramachandra GuHa, India AFter Gandhi: The History of the World's LARGEST DEMOCRACY 746-50 (2007) (detailing the professionalism of Indian civil service and the apolitical nature of the Indian army, from India's founding).

50. Id. at 684-85.

51. SEE THEE KiAN Wie, INDONESIA'S ECONOMY SINCE INDEPENDENCE 120 (2012). See also STEVEn RADELET \& JEFFREY SACHS, THE EAST ASIAN FINANCIAL CRISIS: DIAGNOSIS, REMEDIES, PROSPECTS (1998), available at http://www.cid.harvard.edu/archive/hiid/ papers/bpeasia2.pdf (a contemporary economic analysis of the Asian financial crisis); PAUL Blustein, The Chastening: Inside the Crisis that Rocked the Global Financial SYSTEM AND HUMBLED THE IMF 85-115 (2001) (a journalistic account of the crisis and the IMF's response in Indonesia).

52. SEE Blustein, supra note 51, at 90-92; Donald L. Horowitz, Constitutional CHANGE AND DEMOCRACY IN INDONESIA 32 (2013).

53. SeE Simon ButT \& Tim LindSEy, The Constitution of Indonesia: A ConTEXTUAL ANALYSIS 26-157 (2012); HOROWITZ, supra note 52, at 30-54.

54. SEE BUTT \& LINDSEY, supra note 53, at 51-60, 77-78. 
pensions in Indonesia are all endeavors that raise their own particular, thorny challenges. I highlight some of these particularities in Sections III and IV below. That said, both the Indian and Indonesian laws that I discuss are ambitious attempts to deliver particular forms of social protection on a national scale in developing, middle-income countries. These laws-and the social protection they create-were passed in constitutional orders where socioeconomic rights are recognized and have been judicially reviewed. As discussed in Section I, enforceable socioeconomic rights are becoming more common but are still not commonplace. Therefore, it is worth juxtaposing these recent laws and seeing how they deal with the rights underlying them.

\section{Socioeconomic Similarities}

There are also socioeconomic similarities between India and Indonesia that make comparative analysis compelling. Both countries are very large and very diverse. India is the world's second largest nation, with a population of 1.2 billion. ${ }^{55}$ Indonesia has a population of 250 million, making it the world's fourth largest country. ${ }^{56}$ Both countries are home to an array of linguistic, ethnic, and religious groups. Thus, in both countries, the state shares the challenge of creating norms that can persuade and bind people across a range of cultural contexts and of implementing laws and policies on a large scale.

Both Indonesia and India are lower-to-middle-income countries, 57 though Indonesia is the more economically prosperous of the two. India's annual per capita income is $\$ 1,570,58$ and Indonesia's-at $\$ 3,580^{59}-$ is approximately two-and-a-half times higher. India has far more people who are poor in the absolute sense-it has the world's largest number of extremely poor people, with 23.6 percent or 280 million Indians living on less than a $\$ 1.25$ per day and 59.2 percent

55. SEE OFFICE OF THE REgistraR GENERAL \& CENSUS COMMISSIONER, INDIA, CENSUS OF INDIA 2011, FIGURES AT A GLANCE, available at http://www.censusindia.gov.in/ 2011census/population_enumeration.aspx (last visited Dec. 5, 2014).

56. SEE WORLD BANK, WORLD DeVElopment IndiCATORS: POPUlation DyNamics, available at http://wdi.worldbank.org/table/2.1 (last visited Dec. 5, 2014).

57. Both India and Indonesia are classified as lower-middle-income countries (i.e., those with a GNI per capita within the range $\$ 1,046$ to $\$ 4,125$ ). COUNTRY AND LENDING GROUPS, WORLD BANK, http://data.worldbank.org/about/country-and-lending-groups\# Lower_middle_income (last visited Dec. 6, 2014).

58. Poverty and Equity: India, WORLD BANK, http://povertydata.worldbank.org/poverty/ country/IND (last visited Dec. 5, 2014).

59. Poverty and Equity: Indonesia, WoRLD BANK, http://povertydata.worldbank.org/poverty/country/IDN (last visited Dec. 5, 2014). 
living on less than $\$ 2.00$ per day. ${ }^{60}$ In Indonesia, 16.2 percent of the population survives on less than $\$ 1.25$ per day, and 43.3 percent lives on less than $\$ 2.00$ per day. ${ }^{61}$ However, poverty has been falling fairly steadily in both India and Indonesia, ${ }^{62}$ and declining poverty means that people who are poor aspire to better standards of living, more education for their children, and greater social mobility. When the hopes of the poor are less modest, stark and rising inequality can spark serious friction. At the same time, as material conditions improve, people are better placed to demand more from the state. Thus, there are arguably greater expectations of the state in both countries to cushion the difficult lives of their poorest citizens, as economic growth provides more resources to do so.

Underprivileged Indians and Indonesians encounter public services that are inadequate and, far too often, corrupt. Official corruption thrives in both countries, both at the junior, citizen-facing end of the spectrum as well as at the higher reaches of political power. India ranks 85 th out of 177 countries on Transparency International's corruption perception index, scoring a meager 38 out of 100 points, where a score of 100 would mean the public sector was perceived to be very clean. ${ }^{63}$ Indonesia ranks even lower, and ranks 114th out of 177 countries on the same index. It scores 34 out of 100 points, indicating that the public

60. See Poverty and Equity: India, supra note 58 (showing a table with the percentage of population living at each poverty indicator in India when placing the cursor on the given bar graph).

61. See Poverty and Equity: Indonesia, supra note 59 (showing a table with the percentage of population living at each poverty indicator in Indonesia when placing the cursor on the given bar graph).

62. The percentage of Indians living on $\$ 1.25$ a day fell from $42 \%$ in 2005 to $23.6 \%$ in 2011. See Poverty and Equity: India, supra note 58 (displaying the information on bar graphs with a tab for each year). The percentage of Indonesians living on $\$ 1.25$ a day fell from $22 \%$ in 2005 to $16.2 \%$ in 2011. See Poverty and Equity: Indonesia, supra note 59 (displaying the information on bar graphs with tabs for each year). While absolute poverty has fallen in both countries, individual income inequality has risen in Indonesia over the past decade (though remained fairly steady in India). Indonesia's Gini index rose from 29.0 in 1999 to 38.1 in 2011. See id. at Country Inequality Trend Graph. India's Gini index was 33.4 in 2004 and 33.6 in 2012. See Poverty and Equity: India, supra note 58, at Country Inequality Trend Graph. The Gini index measures the extent to which the distribution of income or consumption expenditure among individuals or households within an economy deviates from a perfectly equal distribution. A Gini index of 0 implies perfect equality, while an index of 100 would mean perfect inequality. GINI INDEX (WORLD BANK ESTIMATE), WORLD BANK, http://data.worldbank.org/indicator/SI.POV.GINI (last visited Jan. 5, 2015).

63. Corruption by Country/Territory, TRANSPARENCY INTERNATIONAL, http://www. transparency.org/country\#IND (last visited May 15, 2015). 
sector is perceived to be very corrupt. ${ }^{64}$ While petty corruption is the lived experience of many, the vast gains from elite rent seeking and nepotism regularly garner headlines. In recent years, political corruption has emerged as an influential electoral issue in India. ${ }^{65}$ In Indonesia, anger over the New Order regime's corruption drove protests against the Suharto government and ultimately brought down President Suharto in 1998.66 Since then, successive governments have pledged measures to curb government corruption, ${ }^{67}$ and it remains a live and emotive issue in Indonesian public life. Any ambitious social protection initiative in either country must grapple with the endemic corruption that deprives people of the goods and services ostensibly being delivered. It is, therefore, worth examining how India and Indonesia have attempted to build accountability into recent social protection laws.

In summary, both Indonesia and India currently face similar demographic and economic challenges as well as opportunities. Both countries have democratic institutions and constitutionally protected rights, providing citizens with both formal and informal ways to pressure the state. State institutions in both countries function poorly, weakened not just by entrenched corruption but also by deep inequities in power and resources. Those shared fundamentals allow for a meaningful comparison between social protection laws in India and Indonesia, albeit one cognizant of the important differences between the two countries.

64. Corruption by Country/Territory, TRANSPARENCY INTERNATIONAL, http://www. transparency.org/country\#IDN (last visited May 15, 2015).

65. See Corruption in India: A Million Rupees Now, Economist, Mar. 12, 2011, available at http://www.economist.com/node/18338852; see also India's Election and the Economy: A Useful Campaign, ECONOMist, Mar. 1, 2014, available at http://www. economist.com/news/asia/21597949-electioneering-focuses-economy-suggests-welcomerealisation-growth-matters; Andrew Buncombe, Indian Election 2014: Corruption and Infrastructure on the Agenda During Biggest Poll So Far, INDEPENDENT, Apr. 10, 2014, available at $\mathrm{http} / / \mathrm{www}$.independent.co.uk/news/world/asia/indian-election-2014-corruptionand-infrastructure-on-the-agenda-during-biggest-poll-so-far-9250769.html; Laurence Cockcroft, Despite the Election, India Still Isn't Confronting Corruption, FoREIGN POL'Y, (May 2, 2014, 5:35 PM), http://foreignpolicy.com/2014/05/02/despite-the-election-india-stillisnt-confronting-corruption; Niharika Mandhana, Upstart Party Scores Victory in India State Elections, WALL ST. J., Feb. 10, 2015, 8:13 AM, http://www.wsj.com/articles/delhielections-aam-aadmi-party-sweeps-to-victory-1423535589.

66. See Sofie Arjon Schütte, Government Policies and Civil Society Initiatives Against Corruption, in Democratization IN POST-SuHARTO INDONESIA 81 (Marco Bünte \& Andreas Ufen eds., 2009).

67. See id. 


\section{A LAW TO FEED THE POOR IN INDIA}

The Indian Parliament passed the National Food Security Act, 2013 (NFSA or "the Act") on September 10, 2013. The Act's avowed aim is to "provide for food and nutritional security ... by ensuring access to adequate quantity of quality food at affordable prices" so that people can "live a life with dignity." 68 The NFSA divided opinion among policy professionals and reportedly even among senior members of the government that proposed the law, ${ }^{69}$ with many commentators considering it fiscally irresponsible and potentially ineffectual. ${ }^{70}$ However, while opponents prescribed policies at variance with the Act, few argued that access to food in India was adequate. India has one of the highest rates of undernutrition in the world, notably higher than countries with lower rates of economic growth and per capita income..$^{71}$

68. The National Food Security Act, No. 20 of 2013, INDIA CODE (2013), pmbl.

69. See e.g., Smita Gupta, NAC Disappointed with Government Draft of Food Security Bill, HINDU, July 22, 2011, available at http://www.thehindu.com/todays-paper/tpnational/tp-otherstates/nac-disappointed-with-government-draft-of-food-security-bill/ article2283919.ece (explaining that many NAC members felt that the final bill was not true to the original intent).

70. For a critical commentary, see Ila Patnalk, Right Hand, Left Hand, INDIAN EXPRESS, Feb. 5, 2013, 3:25 AM, http://archive.indianexpress.com/news/right-hand-lefthand/1069303/3, and Sadanand Dhume, New Delhi's Hunger Games, WaLl ST. J., June 20, 2013, 12:49 PM, http://www.wsj.com/articles/SB10001424127887323393804578557 050745156758. For a summary of the debate, see Avinash Kishore et al., India's Right to Food Act: A Novel Approach to Food Security, in 2013 GLOBAL FOOD POLICY REPORT (International Food Policy Research Institute, 2013), http://www.ifpri.org/gfpr/2013/indiasright-to-food-act?print; and Soutwik Biswas, Is India's Food Security Bill the Magic Pill?, BBC (July 3, 2013, 12:47 PM), http://www.bbc.com/news/world-asia-india-23159706.

71. See UNICEF Data: Monitoring the Situation of Children and Women, Undernourishment in the womb can lead to diminished potential and predispose infants to early death, UNICEF (Nov. 2014), http://www.data.unicef.org/nutrition/low-birthweight (explaining that 28 percent of Indian newborns weigh less than 2,500 grams (or 5.5. pounds), which means they have low birth weight); see also UNICEF Data: Monitoring the Situation of Children and Women, Undernutrition contributes to half of all deaths in children under 5 and is widespread in Asia and Africa, UNICEF (Feb. 2015), http://data.unicef.org/nutrition/malnutrition (showing that over $40 \%$ of children under five have stunted growth in India); Nutrition Landscape Information System: Country Profile India, WORLD HEALTH ORG., http://apps.who.int/nutrition/landscape/report.aspx?iso= IND\&rid=1620\&goButton=Go (last visited June 10, 2015) (describing that $43.5 \%$ of Indian children under five years are underweight for their age and that $17.5 \%$ of the population is below the minimum level of dietary energy consumption). 


\section{A. Policy Background}

Millions of Indians live in chronic hunger, despite a number of government programs that aim to provide food to the hungry. ${ }^{72} \mathrm{~A}$ handful of these are national programs, formulated and financed by the Central Government in New Delhi. ${ }^{73}$ The governments of India's twenty-nine states have devised and financed several programs aimed at providing food to the hungry. The national government has long subsidized Indian farmers to ensure sufficient agricultural productionthe government guarantees that it will buy set amounts of food grain at a "minimum support price."74 Other policies focus on food consumers rather than producers. Some programs subsidize the cost of staple food, such as rice or grain. A long-standing national program supplements staple food with small allowances of protein and cooking oil for the very poor. The national midday meal policy provides primary school children in public schools with school lunches. ${ }^{75}$ Food benefits under these various policies are distributed through a nation-wide network of shops and storage facilities called the public distribution system (the PDS). ${ }^{76}$

Indian food policy is criticized for being needlessly cumbersome, costly, and interventionist. Critics argue that malnutrition results not from a lack of food supply, but from households being unable to afford enough food; from lack of clean water and sanitation facilities, which leads to illness; and from social norms such as families giving girls less food than boys. ${ }^{77}$ Therefore, some policy experts argue that governments should simply supplement the incomes of the poor through food

72. For a summary of national policies on food aid, see Food Schemes, SUPREME COURT COMMISSIONERS (2011), http://www.sccommissioners.org/FoodSchemes/foodschemes.html.

73. These include the Antodaya Anna Yojana, the Integrated Child Development Scheme, the Mid-day Meal Scheme and the Targeted Public Distribution System. For a summary of national policies on food aid, see Food Schemes, supra note 72.

74. Shikha Jha, Food Procurement Policy, in The OxFord COMPANION TO ECONOMICS IN INDIA 196, 196-197 (Kaushik Basu ed., 2007).

75. See Mid Day Meal Scheme, MinisTRY OF HuMAN RES. Dev., http://mdm.nic.in/ (last visited July 10, 2014).

76. See Targeted Public Distribution System, DeP'T of Food AND Pub. DisTrib., http://dfpd.nic.in/?q=node/101 (last visited July 10, 2014).

77. On factors affecting nutrition, see generally LINDSAY H. ALLEN \& STUART R. GILLESPIE, WHAT WORKS? A REVIEW OF THE EFFICACY AND EFFECTIVENESS OF NUTRITION INTERVENTIONS (Joseph M. Hunt, ed., United Nations ACC Sub-Committee on Nutrition \& Asian Development Bank 2001) (reviewing attempts and programs nutrition intervention worldwide), available at http://www.ifpri.org/sites/default/files/publications/ whatworks.pdf. 
vouchers or cash transfers, rather than running food storage and food distribution networks that are inefficient and corrupt. 78

However, many left-leaning policy experts like Drèze and Khera reject these criticisms, pointing out that current policies work well in several states and poorly in others, demonstrating that the Indian government needs to muster political will and accountability rather than devise new policy. ${ }^{79}$ They argue that food-insecure families would suffer if left to the vagaries of local markets, and they point out that the poor are aware of, invested in, and have expressed preferences for the legacy system. ${ }^{80}$ Therefore, these economists press for improving the implementation of the existing food programs and for tackling corruption in the delivery system.

The NFSA emerged from this policy context and attendant debate. However, the specific demand for a law was influenced by public interest litigation that challenged particular food policy failures. During the long-running PUCL case, discussed in more detail below, the Supreme Court of India ("Supreme Court") recognized an individual right to food. The Supreme Court's articulation of this right, in turn, gave civil society groups a lever with which to demand a law on food for the poor.

\section{B. Constitutional Framework}

Judicial recognition of the right to food followed a body of jurisprudence recognizing social and economic rights that are not included in the Indian Constitution's catalogue of fundamental rights. ${ }^{81}$ All of the rights recognized in the Constitution as fundamental-except one, the right to education-are civil and political rights." 82 Basic goods

78. See Patnalk, supra note 70, for policy arguments against distributing food grain rather than cash, and see Dhume, supra note 70 , for similar arguments by a journalist. For a summary of the debate about whether the government should distribute food grain or cash to the poor, see Lola Nayar, The Ration Card Route, OuTLOOK, Dec. 30, 2013, available at http://www.outlookindia.com/article/The-Ration-Card-Route/288912.

79. See Jean Drèze \& Reetika Khera, Revival of the Public Distribution System: Evidence and Explanations, ECON. \& POL. WEEKLY, Nov. 5, 2011, at 36 (explaining the problems within the public distribution system); see also Jean Drèze \& Reetika Khera, Rural Poverty and the Public Distribution System, ECON. \& POL. WEEKLY, Nov. 16, 2013, at 55 (explaining the impact of a public distribution system on rural poverty).

80. See Jean Drèze \& Reetika Khera, Food us. Cash, OuTlOoK, Mar. 24, 2014, available at http://www.outlookindia.com/article/Food-Vs-Cash/289804 (explaining poor families' dependence on the Public Distribution System).

81. INDIA CONST, arts. 12-35.

82. INDIA CONST. art. 21A, amended by The Constitution (Eighty-Sixth Amendment) Act, 2002 (recognizing the fundamental right of all children aged six to fourteen years to free and compulsory education). 
and services such as healthcare, water, food, and sanitation were not included as fundamental rights in the Indian Constitution, but were included as "Directive Principles of State Policy."83 The principles are meant to shape government policy and priorities-they are "fundamental in the governance of the country" but, expressly, are not "enforceable by any court." 84 The Supreme Court has diluted that restriction through a series of decisions in response to public interest litigation (PIL) focusing on vulnerable groups. In PIL decisions involving social and economic rights since the 1980s, the Supreme Court of India has drawn on the directive principles to interpret the constitutional right to life-further holding that a meaningful conception of the right to life encompasses rights to water, shelter, education, emergency medical care, and a decent environment. ${ }^{85}$ For example, in Francis Coralie Mullin, Justice Bhagwati said:

We think that the right to life includes the right to live with human dignity and all that goes along with it, namely, the bare necessities of life such as adequate nutrition, clothing and shelter and facilities for reading, writing and expressing oneself in diverse forms, freely moving about .... and co-mingling with fellow human beings. ${ }^{86}$

The Indian Supreme Court has, in effect, acknowledged that socioeconomic necessities can be treated as justiciable rights and can be enforced by the judiciary. In PIL cases, the Supreme Court devised special remedies such as appointing expert rapporteurs and using "continuing mandamus"-a series of interim orders issued at periodic court hearings-to monitor government progress on judicial directions. ${ }^{87}$

This jurisprudence was well established when an NGO, the People's Union of Civil Liberties, filed a public interest petition in April 2001 on

83. These are contained in Part IV of the Constitution, titled "Directive Principles of State Policy." INDIA CONST. arts. 36-51.

84. INDIA CONST. arts. 36-51.

85. See, e.g., Singh v. Pradesh, (1995) 6 S.C.R. Supp. 827 (India); Mullin v. Adm'r, Union Territory of Delhi, (1981) 2 S.C.R. 516 (India); Tellis v. Bombay Mun. Corp., (1985) 2 S.C.R. Supp. 51 (India); Paschim Bangal Khet Mazdoor Samity ORS. v. W. Bengal, (1996) 4 S.C.C. 37 (India) (providing a sample of the Supreme Court of India's decisions); see also Surabhi Chopra, Holding the State Accountable for Hunger, 44 ECON. \& PoL. WEEKLY, Aug. 15, 2009, at 8, 10; Forster \& Jivan, supra note 38, at 4-6.

86. Mullin v. Adm'r, Union Territory of Delhi, (1981) 2 S.C.R. 516, 518 (India).

87. Chopra, supra note 85, at 11; Forster \& Jivan, supra note 38, at 16, 18. 
behalf of people facing acute hunger in north and east India. ${ }^{88}$ The petition challenged government failure to assist the rural poor in these regions, many of them subsistence farmers, whose livelihoods had been so badly hurt by a few years of consecutive drought that they could no longer afford sufficient food. The petitioners claimed that the failure of welfare programs to effectively distribute food in these circumstances violated state obligations under the constitutional right to life. ${ }^{89}$ They argued, in effect, that the right to life included within it the right to be free from hunger.

The Supreme Court, consistent with its approach to other essential goods and services, responded favorably to the petitioners-impliedly concurring that the right to food was indeed a part of the fundamental right to life. ${ }^{90}$ The Court added several state governments from different parts of India as respondents in the case and asked officials to report on the status of food welfare programs. ${ }^{91}$ In the following years, the Court issued interim orders that, inter alia, converted the benefits of nine nutrition programs into legal entitlements and expanded coverage of primary school midday meals and other child welfare programs. ${ }^{92}$ Since corruption was a chronic obstacle at the village level, the Supreme Court directed greater transparency in implementing food programs, ${ }^{93}$ requiring that court orders and lists of eligible beneficiaries be prominently displayed in the local language at government buildings and PDS shops across India. It further ordered that members of the public at the village level were entitled to initiate social audits of those schemes. ${ }^{94}$ Left-leaning civil society groups coalesced around this longrunning PIL and, over time, began demanding a law to ensure adequate food for the poor. Their campaign found some traction with the national

88. People Union for Civil Liberties v. Union of India, 196 of 2001, civil writ of petition, para. 2, 25, 31, available at http://www.righttofoodindia.org/case/petition.html.

89. INDIA CONST. art. 21.

90. Supreme Court of India, Order of July 23, 2001 in People Union for Civil Liberties v. Union of India, 196 of 2001, civil writ of petition, available at http://www. righttofoodindia.org/orders/july23.html.

91. Id.

92. Supreme Court of India, Order of Nov. 28, 2001 in People Union for Civil Liberties $\mathrm{v}$. Union of India, 196 of 2001 , civil writ of petition, para. 1-8, available at http://www. righttofoodindia.org/orders/nov28.html; Supreme Court of India, Order of Apr. 20, 2004 in People Union for Civil Liberties v. Union of India, 196 of 2001, civil writ of petition, available at http://www.righttofoodindia.org/orders/apr2704.html.

93. Supreme Court of India, Order of Nov. 28, 2001 in People Union for Civil Liberties v. Union of India, 196 of 2001, civil writ of petition, para. 9-11, available at http://www. righttofoodindia.org/orders/nov28.html.

94. Supreme Court of India, Order of May 8, 2001 in People Union for Civil Liberties v. Union of India, 196 of 2001, civil writ of petition, para. (f), available at http://www. righttofoodindia.org/orders/may8.html. 
government, ${ }^{95}$ but given the deep divisions among policy experts, it took a few years to develop a draft law that the government supported enough to place before the Parliament and put to a vote.

\section{The Ambit of the Law}

Thus, the National Food Security Act was preceded by protracted public interest litigation and sits atop various national and state policies. The Act creates the framework within which governments must deliver food benefits and assigns obligations in this regard. It lays down what individuals are entitled to. It also attempts to create a mechanism for holding governments accountable when they fail to meet their obligations.

\section{Entitlements}

A "first principles" approach to food entitlements would factor in the different types of food needed for a balanced, healthy diet, drawing on widely accepted nutritional guidelines formulated by expert bodies such as the World Health Organization.96 For example, the Food and Agricultural Organization advises defining food or nutrition security as, inter alia, stable access to a nutritious diet, as well as to sufficient water, healthcare, and sanitation to utilize nutrition adequately. ${ }^{97}$ Many states would not be able to provide food security defined in this way, but following the ICESCR, those states could work toward meeting this standard while providing the maximum that is currently feasible.

The NFSA neither draws on expert guidelines nor sets an aspirational standard to be progressively realized. Instead, under the Act, individuals in households falling below the official poverty line get a specified amount of food-five kilograms of grain-every month at subsidized rates from PDS shops. ${ }^{98}$ Households that are identified as extremely poor get an additional quota of subsidized grain-thirty-five kilograms-every month. ${ }^{99}$ The Act does not define food or nutrition

95. See Indian National Congress, LoK SABHa Elections 2009 MaNifesto of THE INDIAN NATIONAL CONGRESS (2009), available at http://inc.in/documents/electiondoc/manifesto09-eng.pdf (during national elections in 2009, the election manifesto of the Indian National Congress, which led the ruling United Progress Alliance, included a pledge "to enact a Right to Food law that guarantees access to sufficient food for all people, particularly the most vulnerable sections of society").

96. See WHO Guidelines on Nutrition, WORLD HEALTH ORG., http://www.who.int/ publications/guidelines/nutrition/en/ (last visited Apr. 22, 2015).

97. FAO Guide, supra note 41 , at 73.

98. The National Food Security Act, No. 20 of 2013, INDIA CoDE (2013), § 3(1).

99. Id. 
more generally and defines "food security" simply as the "supply of the entitled quantity of food grains." 100 If the government fails to supply food-grain to an eligible individual, the NFSA entitles that person to a monetary allowance in lieu of grain. The national government has the power to lay down the amount of the allowance and the procedure for claiming it. ${ }^{101} \mathrm{Up}$ to 75 percent of India's rural population and up to 50 percent of its urban population can be put into the category of people entitled to subsidized grain. ${ }^{102}$

\section{Obligations}

While the entitlement to food-grain is narrow, delivering it in a country as large as India is complicated, and the NFSA imposes obligations on national, state, and local governments in this regard. The national government is bound, under the Act, to "ensure" the regular supply of grain to eligible households. ${ }^{103}$ To do this, the relevant national ministries in New Delhi must procure grain, allocate it among different states, and arrange for it to be transported across India in the requisite quantities. ${ }^{104}$ Since the Act is legalizing what was previously a policy commitment, if the national government cannot procure enough grain within India, it would now be obligated to import the shortfall despite the fiscal burdens this might impose.

It is the governments of India's twenty-nine states that are responsible for implementing the details of the NFSA. The Act makes them responsible for implementing the full range of national and statespecific food welfare programs ${ }^{105}$ and ensuring "actual delivery of entitled benefits." 106 In practice, this legal obligation includes multiple, interconnected steps cutting across a range of public bodies: ensuring that grain is stored properly; ensuring that grain reaches PDS shops rather than being diverted to private wholesalers; and ensuring that shops open as required, display information about prices and NFSA entitlements, and do not dilute or contaminate the grain to make it stretch further. Most fundamentally, state governments must identify the individuals and households who are poor and extremely poor, and therefore, entitled to food benefits. ${ }^{107}$

\footnotetext{
100. Id. $\S 2(6)$.

101. Id. $\S 8$.

102. $I d . \S 3(2)$.

103. Id. §22(1).

104. $I d . \S 22$.

105. Id. § 24 .

106. Id. § 24(3).

107. Id. § 10(1).
} 
Within each state, local governments play a crucial role in ensuring delivery to the individual and guarding against the inefficiencies and corruption within the food distribution system. Local-level officials identify households and individuals eligible for food-grain and check that the community PDS shop functions well. Clearly, a corrupt official at the grassroots level could undermine the Act, making food-security subject to patronage and payment. Local officials' "last mile" role notwithstanding, the NFSA does not detail their obligations. Instead, the Act assigns local authorities the general responsibility to ensure "proper implementation ... in their respective areas"108 and obligates them to do what the state government asks of them. ${ }^{109}$

This allows the state government to be flexible and sensitive to context. Food provision in Himalayan villages in northern India might require different systems from villages in the drought-prone plains of the northwest. At the same time, leaving state governments to set locallevel standards allows regional disparities in public services to persist. ${ }^{110}$ For example, the government of the southern state of Tamil $\mathrm{Nadu}$, which provides reasonably efficient public services, might impose more exacting duties on local authorities than the government of Uttar Pradesh in the north, which has a long record of poor service delivery.

\section{Special Measures for Vulnerable Groups}

Just as the NFSA leaves local authority regulation to state governments, it also leaves to them the question of special measures for vulnerable groups. Under the ICESCR, states have a specific obligation to prevent discrimination in access to economic and social rights. ${ }^{111}$ This obligation, which falls within a state's immediately effective, minimum core duties, ${ }^{112}$ is very relevant in India's deeply unequal context. Historically disadvantaged caste groups, tribal communities, and particular religious minorities are overrepresented among India's poor (and therefore, among people living with chronic hunger). These groups

108. Id. $\S 25$.

109. $I d . \S 26$.

110. See Ankita Aggarwal, Why Bihar's Child is Different from Himachal's, INDIA TOGETHER (Apr. 8, 2014), http://indiatogether.org/how-icds-works-in-different-stateschildren; Jean Drèze \& Reetika Khera, Water For The Leeward India, OUTLOoK, Mar. 24, 2014, available at http://www.outlookindia.com/article.aspx?289801.

111. International Covenant on Economic, Social and Cultural Rights, art. 2, ๆ 2, Dec. 16, 1966, U.N.T.S. I-14531.

112. Comm. on Economic, Social and Cultural Rights, General Comment 20, NonDiscrimination in Economic, Social and Cultural Rights (art. 2, para. 2), May 4-22, 2009, I 7, U.N. Doc. E/C.12/GC/20 (May 25, 2009) [hereinafter CESCR General Comment 20]; CESCR General Comment 3, supra note 30, ๆ 1, 5 . 
continue to face discrimination in public life, including in access to public services. ${ }^{113}$ Cutting across different groups, women in India are considerably less free and less safe than their male compatriots, both in private and in public. The female-to-male ratio in India is one of the lowest in the world,114 resulting not just from sex-selective abortion of female fetuses, but also higher mortality rates for young girls as compared to young boys. Gendered neglect and disregard of young girls runs so deep that proportionately more girls die in infancy and those who survive have less access to schooling, healthcare, and food as they grow. ${ }^{115}$

The NFSA lays down special entitlements for women and children, but avoids clear-cut measures for other groups. Instead, the Act vaguely exhorts state governments to "give special focus" to the needs of "vulnerable groups," "especially in remote areas and other areas which are difficult to access, hilly and tribal areas for ensuring their food security,"116 leaving room for group benefits but not requiring them.

The nutritional needs of young children receive special protection in the Act. Children aged six to fourteen years are entitled to a free lunch every day in public or government-aided schools. ${ }^{117}$ Children below school-going age are similarly entitled to a free meal at their local public childcare center. ${ }^{118}$ These provisions put on a statutory footing a longrunning food-welfare program. The midday meal program has been in place for over ten years across India, and provides weekday lunches to over 120 million children. ${ }^{119}$ Research shows that student enrollment, attendance, ${ }^{120}$ and retention ${ }^{121}$ in primary schools have risen as a result of the program. Given India's high rates of malnutrition in children, free school lunches have direct nutritional benefits for children from families

113. See, e.g., Human Rights Watch, Hidden Apartheid: Caste Discrimination AGAINST INDIA'S UNTOUCHABLES 39, 41 (2007), available at http://www.hrw.org/reports/ 2007/india0207/2.htm (Hidden Apartheid was produced as a "shadow report" to the UN Committee on the Elimination of Racial Discrimination).

114. See, Gender Composition, Office of THE Registrar Gen. \& Census Comm'r, INDIA, censusindia.gov.in/Census_And_You/gender_composition.aspx (last visited Apr. 23, 2015) (the sex ratio in India in 2011 was 940 women to 1000 men).

115. JEAN DRĖze \& AMARTYA SEN, INDIA: DEvElOPMENT AND PARTICIPATION 229-234 (2002).

116. The National Food Security Act, No. 20 of 2013, INDIA CODE (2013), 330.

117. $I d . \S 5(1)(\mathrm{b})$.

118. $I d . \S 5(1)(\mathrm{a})$.

119. Reetika Khera, Mid-Day Meals: Looking Ahead, ECoN. \& Pol. WeEkLY, Aug. 10, 2013, available at http://www.epw.in/commentary/mid-day-meals-looking-ahead.html.

120. See Farzana Afridi, The Impact of School Meals on School Participation: Evidence from Rural India, 47 J. DEv. STUD. 1636, 1652 (2011).

121. Khera, supra note 119 . 
living on the brink of hunger. ${ }^{122}$ Proponents of the program argue that it also has more diffuse advantages, such as weakening persistent caste taboos, as children from traditionally "low" and "high" castes eat the same food, side by side. ${ }^{123}$ The program is popular with parents, which has led different governments to support it regardless of the particular political party in power. ${ }^{124} \mathrm{So}$, in putting the midday meal program on a statutory footing, the NFSA is not actually creating new protections for young children, but is making an existing, popular, and effective measure more secure.

Some of the NFSA's provisions on women are potentially more contentious. Under the Act, pregnant women and lactating mothers are entitled to a free meal every day during pregnancy and for six months after giving birth, supplemented by monetary maternity benefits of approximately one hundred dollars. ${ }^{125}$ These prenatal and postnatal entitlements are unlikely to be controversial. However, the NFSA recognizes women not just as child bearers but as citizens and public actors. The oldest woman in a household is designated, under the Act, as the "head of the household" who holds the necessary eligibility documents and collects the family's food entitlements. ${ }^{126}$ Only if a household has no adult women can the oldest man in the family serve as head of household, but the Act requires that he cede this role when a girl in the family turns eighteen. ${ }^{127}$

Granting women exclusive authority to collect food disbursements reflects the practical reality that women cook food within the home and, when food is scarce, bear the burden of stretching what is available to feed their families. In addition, this measure also reflects recent research that suggests welfare gains, particularly for children, are higher when women influence how families use public goods and services. ${ }^{128}$ These provisions build on past efforts by the state in India to

122. See Farzana Afridi, Child Welfare Programs and Child Nutrition: Evidence from a Mandated School Meal Program in India, 92 J. DEV. ECON. 152, 158-62 (2010).

123. Khera, supra note 119.

124. Id.

125. The National Food Security Act, No. 20 of 2013, INDIA CoDE (2013), $\$ 4$.

126. Id. $\S 13$.

127. Id. §13(2).

128. DRĖZE \& SEN, supra note 115, at 271-74; For a discussion on the effects of women's engagement with public services, see, for example, Eleanor MacPherson, Invisible Agents: Women in Service Delivery Reforms, 38 InST. DeV. STUD. BULL. 38, 39-40 (2008); Benjamin Davis et al., The Lure of Tequila and the Bestowing of Motherly Love: Does it Matter Whether Public Cash Transfers are Given to Women or Men? Evidence from the PROGRESA and PROCAMPO Programs in Rural Mexico (Euro. Ass'n Agric. Economists, 2002); Xiaohui Hou, Women's Decision Making Power and Human Development: Evidence from Pakistan (World Bank, Human Development Social Protection Unit, South Asia Region, Working Paper No. 5830, 2011), available at http://econ.worldbank.org/external/ 
strengthen women's agency. For example, during village council elections in India, leadership positions are reserved for women in a fraction of randomly chosen councils. In another example, many microcredit providers in South Asia prioritize giving loans to women. ${ }^{129}$ Despite strong cultural constraints, women have asserted themselves in these roles. ${ }^{130}$ The NFSA takes seriously the lessons from these past experiences. In much of India, neither cultural norms nor religious law would countenance a woman being the head of her household. By designating women as such, this law recognizes intersecting forms of vulnerability and stitches the effort to shift women's low status into the overarching aim of providing food to the poor.

\section{Accountability Measures}

The aim animating the NFSA is getting food-in particular basic staple grains-into the hands of those who cannot afford to feed themselves. Past experience shows that many people cannot rely on accessing food benefits because they are left off the list of eligible beneficiaries or because their local PDS shop does not open when it should. Since the NFSA largely preserves preexisting policies, those problems remain relevant. In response, the Act puts in place different mechanisms to monitor government performance.

The NFSA authorizes the national government to appoint independent auditors to evaluate welfare programs. ${ }^{131}$ Variations among states could be highlighted using this power, nudging state governments that perform poorly to improve. While allowing the central government in New Delhi to initiate professional audits, the Act requires local governments to conduct regular "social audits" on welfare programs as well as on PDS shops. ${ }^{132}$ Community residents are to be

default/main?pagePK=64165259\&theSite $\mathrm{PK}=469382 \&$ pi $\mathrm{PK}=64165421 \&$ menuPK=641660 93\&entityID=000158349_20111005120527.

129. There is considerable literature on the effects of microcredit programs focused on women. See, e.g., Supriya Garikipati, The Impact of Lending to Women on Household Vulnerability and Women's Empowerment: Evidence from India, 36 WORLD DEV. 2620 (2008) (finding that although lending programs benefit households, they fail to empower women); Naila Kabeer, Conflicts Over Credit: Re-Evaluating the Empowerment Potential of Loans to Women in Rural Bangladesh, 29 WoRLD DEv. 63 (2001) (examining the different conclusions reached by evaluations of credit programs for rural women in Bangladesh); Syed M. Hashemi et al., Rural Credit Programs and Women's Empowerment in Bangladesh, 24 WORLD DEV. 635 (1996) (studying two credit programs to rural women in Bangladesh, and finding that they have significant effects on empowerment).

130. BANERJEE \& DUFLO, supra note 43 , at 250-51.

131. The National Food Security Act, No. 20 of 2013, INDIA CoDE (2013), $\$ 4$.

132. Id. $\S \S 2(20), 28$. 
included among the auditors, and audit results must be made public. Social audits are an established part of the civil society toolbox in rural India. In response to poor public services, many Indian NGOs began organizing unofficial public hearings and performance audits in the 1990 s, ${ }^{133}$ sometimes in partnership with government ${ }^{134}$ and sometimes in opposition to it. Goetz and Jenkins observe that citizens have usually been restricted to "vertical" modes of holding government accountablelobbying interspersed periodically by voting-and argue that civil society in India is trying to insert itself into "horizontal" accountability processes through audits, public hearings, and public interest litigation. ${ }^{135}$ To harness the potential of what they term "hybrid accountability," Goetz and Jenkins recommend that laws and policies should formalize citizens' scrutiny of government performance by giving NGO observers legal standing to observe the full scope of a public authority's work as well as structured access to official records. ${ }^{136}$ The NFSA takes this advice, at least partially, and incorporates civil society participation at the grassroots. In addition to institutionalizing community oversight, the Act requires that all official records tied to food distribution be proactively disclosed and readily available for inspection by members of the public. ${ }^{137}$

Social audits provide a platform for local residents to evaluate how effectively food is being delivered, but the government initiates the evaluative exercise. However, the NFSA also allows individuals to complain or "file a grievance" with a local official if they are denied the grain to which they are entitled. 138 State governments are also required by the Act to set up complaints mechanisms such as call centers and help lines. ${ }^{139}$ This provision might seem like an unnecessary point of detail, but it is a useful response to the lived experience of welfare beneficiaries. Individuals are routinely deprived of benefits, but complaining about this deprivation is difficult. The indigent citizen, in particular, typically approaches officials as a supplicant, often waiting hours for an audience. In this context, requiring proactive disclosure of information, accessible complaint mechanisms, and participatory

133. See Anne Marie Goetz \& Rob Jenkins, Hybrid Forms of Accountability: Citizen Engagement in Institutions of Public-Sector Oversight in India, 3 PUB. MGMT. R. 363, 37075 (2001), for an early example of using social audits to monitor food welfare programs in India.

134. Id.

135. Id. at 364 .

136. Id. at 369 .

137. The National Food Security Act, No. 20 of 2013, INDIA CoDE (2013), § 27.

138. Id. $\S 14$.

139. Id. 
performance audits signals a conscious attempt to make local government more accountable to individuals.

Higher up the administrative chain, the Act requires the government of each state to set up a quasi-independent watchdog, or "Food Commission," to monitor implementation of the Act. ${ }^{140}$ Each Food Commission is financed by the respective state government, which also has the power to appoint and remove members, albeit within parameters set by the NFSA. ${ }^{141}$ Commissioners are drawn both from inside and outside the government. ${ }^{142}$ The Food Commission is required to advise the government on food policy and programs. ${ }^{143}$ In addition, it has the authority to receive complaints from individuals, both in an appellate and in an original capacity. Someone unhappy with the response from the local government grievance officer can appeal to the Food Commission. ${ }^{144}$ The Food Commission can also receive direct complaints about "violations of entitlements" and can inquire on its own initiative into actual or suspected violations. ${ }^{145}$

Whether responding to a complaint or initiating its own investigation, the Food Commission's powers of inquiry are considerable. It is endowed with "all the powers of a civil court while trying a suit under the Code of Civil Procedure."146 With these powers, the Food Commission can summon and examine under oath anyone it considers appropriate, order discovery and production of documents, and requisition official public records from anywhere in India. Proceedings before a food commission are a serious mattercommissioners can initiate criminal proceedings for contempt of court against parties if necessary. ${ }^{147}$ However, a food commission cannot issue binding orders as a court of law would be able to-it can only recommend a particular course of action to the government.

Thus, the NFSA sets up a handful of different mechanisms to evaluate government performance in general as well as to raise individual complaints. Indonesian laws on social security, which are discussed below, share that concern with accountability.

\footnotetext{
140. Id. § 16(1).

141. Id. §16(9).

142. Id. $\$ 16$.

143. Id. $\$ 16(6)(\mathrm{c})-(\mathrm{d})$.

144. Id. $\$ 16(6)(\mathrm{e})$.

145. Id. $\$ 16(6)(\mathrm{b})$.

146. Id. §20(1).

147. Under Section 20(2) of the NFSA, a food commission can pass a case on to a judicial magistrate where it is treated as originating in a police complaint by the commission, and charged and tried under section 346 of the Code of Criminal Procedure, 1973 (CODE CRIM. PROC. § 346).
} 


\section{CREATing “CRADle to GRaVE” Social SECURITy IN INDONESIA}

The Indonesian legislature, the Dewan Perwakilan Rakyat or House of Representatives, passed the law concerning the National Social Security System ${ }^{148}$ (Undang Undang Sistem Jaminan Sosial Nasional or SJSN) in September 2004. In order to create a "national social security system," SJSN mandates multiple types of social security for Indonesians, including health insurance, old-age pensions, work accident insurance, and death benefits. ${ }^{149}$ Seven years later, in 2011 , the legislature followed SJSN with the law concerning the Social Security Administrative Body ${ }^{150}$ (Badan Penyelenggara Jaminan Sosial or "the BPJS law"), which created institutions to implement the social security system required by SJSN.

\section{A. Policy Background}

The Indonesian State has provided social insurance-including health insurance, old age insurance, and pensions-to civil servants, the police force, and members of the armed forces for several decades. ${ }^{151}$ Since 1992, similarly modeled social insurance has also been available for private sector workers, but only those who work within the formal economy. ${ }^{152}$ These insurance programs are contribution based and have been managed by purpose-built state-owned enterprises, some of which have a favorable reputation and some of which have a reputation for unreliability. ${ }^{153}$ Indonesians who work within the informal economy-an

148. Undang-Undang Republik Indonesia Nomor 40 Tahun 2004 Tentang Sistem Jaminan Sosial Nasional (Law of the Republic of Indonesia Number 40 Year 2004 About the National Social Security System) (Indon.) [hereinafter SJSN].

149. SJSN, art. 18.

150. Undang-Undang Republik Indonesia Nomor 24 Tahun 2011 Tentang Badan Penyelenggara Jaminan Sosial (Law of the Republic of Indonesia Number 24 Year 2011 About The Social Security Administrator) (Indon.).

151. For a brief discussion of social insurance measures, see Muliadi Widjaja \& Robert A. Simanjuntak, Social Protection in Indonesia: How Far Have We Reached?, in SocIAL Protection in EAst Asia - CURRENT STATE AND Challenges 157, 159 (M.G. Asher et al. eds., 2010); Dinna Wisnu, Indonesia's Experience with Targeting Schemes, is it Heading Towards Universal Coverage? Case of PNPM and PKH 3 (July 25, 2013) (unpublished manuscript) (on file with author).

152. See Alex Arifianto, The New Indonesian Social Security Law: A Blessing or Curse for Indonesians?, 23 ASEAN ECON. BULLETIN 57, 58-60 (2006); Widjaja \& Simanjuntak, supra note 151 , at $172-74$.

153. Widjaja \& Simanjuntak, supra note 151, at 167-68, 175; Arifianto, supra note 152, at 61 . 
estimated 65 percent of Indonesian workers, including Indonesia's poorest citizens-are not covered by social insurance. ${ }^{154}$

Alongside social insurance for formal-economy workers, the Indonesian government ran, and continues to run, social assistance programs for the poor that provide cash or essentials such as food. ${ }^{155}$ For example, the Program Keluarga Harapan transfers cash to pregnant women and mothers to access basic healthcare and education for themselves and their children. ${ }^{156}$ Another recent social assistance program experiments with decentralization-the PNPM Mandiri program, which grants funds to local governments and allows community members to decide how to spend the money. ${ }^{157}$

Thus, the poor in Indonesia receive social assistance from the state but do not have social insurance like many of their more privileged counterparts. SJSN made a bid to change that. This law stipulates five benefits-health, pension, old-age savings, death benefits, and worker accident insurance-for all Indonesians. Universalizing social insurance, as SJSN sought to do, was extraordinarily ambitious. It required not just combining the existing social insurance programs but also extending these safety nets on a scale that has no close precedent. As the World Bank has noted, "[N]o other country with such a large informal sector has implemented a national social insurance scheme covering all workers." 158

SJSN was formulated during the period of deep political reform that followed the Asian financial crisis and Suharto's subsequent, dramatic fall from power. Big transitions can embolden policy makers, 159 and SJSN's ambition certainly seems like a direct result of Indonesia's

154. Int'l Monetary Fund, Indonesia: Selected Issues, IMF Country Report No. 15/75, at 23 (Mar. 2015), available at http://www.imf.org/external/pubs/ft/scr/2015/cr1575.pdf. The World Bank estimates the number of workers in the informal economy in Indonesia to be one million. See World Bank, Implementation of BPJS Ketenagakerjaan, POL'Y NOTE ON SJSN, May 2012, at 3, available at http://documents.worldbank.org/curated/en/2012/05/ 16394353/implementation-social-security-administrative-bodies-bpjs-ketenagakerjaan.

The Informal Sector Survey by the Indonesian Bureau of Statistics in 2009 indicated that the percentage of people in non-agricultural informal sector was $72 \%$. See Int'l Labour Org. Dep't of Statistics, Statistical Update on Employment in the Informal Economy 4, tbl.1 (June 2012), available at http://laborsta.ilo.org/applv8/data/INFORMAL_ECONOMY/ 2012-06-Statistical\%20update\%20-\%20v2.pdf.

155. Wisnu, supra note 151, at 41 ; Widjaja \& Simanjuntak, supra note 151 , at 159.

156. Wisnu, supra note 151 , at 3-15.

157. Id.

158. Policy Note on SJSN: Implementation of BPJS Ketenagakerjaan, WORLD BANK (May 1, 2012), http://documents.worldbank.org/curated/en/2012/05/16394353/implementationsocial-security-administrative-bodies-bpjs-ketenagakerjaan.

159. Merilee S. Grindle \& John W. Thomas, Public Choices and Policy Change: The Political Economy of Reform in Developing Countries 14 (1991). 
economic trauma and tumultuous democratization in the late 1990s. In 1998 , Indonesia's economic output contracted by 14 percent-a sharper fall than any country had experienced since the Great Depression of the 1930 s. ${ }^{160}$ Median daily wages fell by 30 percent in rural areas and 40 percent in urban areas, pushing hundreds of thousands of Indonesians into poverty. ${ }^{161}$ Wisnu notes that in the aftermath of the financial crisis, influential voices advocated a systematic response to the rise in poverty rather than an ad hoc temporary measure. ${ }^{162}$ In 2002, the Indonesian government created an internal task force to draft the law. This task force had no representatives from trade unions or private-sector employers, and critics point out that the law was drafted and passed in haste, without adequate consultation or the necessary planning and financial forecasting. ${ }^{163}$

\section{B. Constitutional Framework}

When SJSN was drafted, the Indonesian government was confronting both pressure and opportunity. President Megawati Sukarnoputri's government needed to communicate that it was committed to ordinary Indonesians (who could now vote and criticize the state far more than was previously the case). In addition, the Indonesian Constitution, Undang-Undang Dasar $1945^{164}$ ("the constitution"), had been amended to include the right to social security for individuals.

Article $28 \mathrm{H}$ of the Indonesian Constitution states that all Indonesians have the right to social security, "in order to develop oneself fully as a dignified human being." 165 Article 34(2) imposes an obligation to provide social security on the state. It provides that "impoverished persons and abandoned children shall be taken care of by the State" and requires the state to "develop a system of social security for all of the people" and, more expansively, to "empower the inadequate and underprivileged . . . in accordance with human dignity."166 Article 34 also obligates the state to "provide sufficient medical and public service facilities."

160. BLUSTEIN, supra note 51, at 87.

161. Id.

162. Wisnu, supra note 151 , at 2 .

163. Arifanto, supra note 152 , at 65 .

164. Undang-Undang Dasar Negara Republik Indonesia Tahun 1945 [CONSTITUTION] 1945 , art: $28 \mathrm{H}$ (Indon.).

165. Id. art. $28 \mathrm{H} \S 3$.

166. Id. art. 34(2). 
These provisions were added to the Indonesian Constitution during four crucial constitutional amendments between 1999 and 2003, which transformed Indonesia's authoritarian political system into a democracy. ${ }^{167}$ The second amendment, added in 2000, inserted a catalogue of human rights into the constitution, ${ }^{168}$ including civil and political rights as well as the economic and social rights to, inter alia, ${ }^{169}$ shelter, ${ }^{170}$ medical care, ${ }^{171}$ social security, ${ }^{172}$ a healthy environment, ${ }^{173}$ an education, ${ }^{174}$ and improvement of one's welfare. Article 28(I) obligates the state to protect, advance, and fulfill all these constitutional rights. In addition, the constitution imposes express positive duties on the state in relation to particular rights, including social security. As noted in Section I, socioeconomic rights are now recognized in many national constitutions, particularly those drafted during democratic transitions in the 1990s. Even so, the Indonesian Constitution is unusual in both the number and type of socioeconomic rights ${ }^{175}$ it recognizes, and in specifically imposing positive duties on the state.

The reformasi era resulted not just in constitutional rights, but also an independent judiciary ${ }^{176}$ and the establishment in 2003 of a constitutional court that has the power to review legislation. ${ }^{177}$ In early judicial review decisions involving economic policy, the Constitutional Court was surprisingly bold. Controversially, the Court struck down a law privatizing the electricity sector in 2004 based on a rather vague constitutional provision that requires the state to retain power over "sectors of production which are important for the country and affect the life of the people."178 In a subsequent decision that engaged the same provision, the Court upheld, but closely reviewed, a law regulating the

167. For an account of constitutional reform during these years, see Tim Lindsey, Constitutional reform in Indonesia: Muddling Towards Democracy, in INDONESIA: LAW AND SOCIETY 23-42 (Tim Lindsey ed., 2d ed. 2008).

168. Undang-Undang Dasar Negara Republik Indonesia Tahun 1945 [ConstituTION] 1945, ch. XA (Indon.) (amended 2000).

169. Id. art. $28 \mathrm{C}$.

170. Id. art. $28 \mathrm{H} \S 1$.

171. Id.

172. Id. art. $28 \mathrm{H} \S 3$.

173. $I d$. art. $28 \mathrm{H} \S 1$.

174. Id. art. $28 \mathrm{C} \S 1$.

175. Jung et al. show that while about $70 \%$ of current constitutions contain at least one expressly justiciable social and economic right (most typically the right to education), only $25 \%$ contain ten or more social and economic rights. See Jung et al., supra note 3, at 8 .

176. Undang-Undang Dasar Negara Republik Indonesia Tahun 1945 [CoNsTITUTION] 1945, art. 24B (Indon.) (amended 2000).

177. $I d$. art. $24 \mathrm{C} \S 1$.

178. Phillippa Venning, Determination of Economic, Social and Cultural Rights by the Indonesian Constitutional Court, 10 AUSTL. J. ASIAN L. 100, 114-18 (2008). 
water sector. ${ }^{179}$ On the whole, the Constitutional Court has veered between interpreting strongly worded socioeconomic rights quite literally and being more deferential to the executive. For example, the Court held that the constitutional duty to spend 20 percent of the state's budget on education is immediately binding, rejecting the government's argument to the contrary, yet it declined to invalidate provincial budgets that failed to fulfill this ostensibly binding duty. ${ }^{180}$ However, even if the Constitutional Court's early literalism has been tempered, there is no doubt that socioeconomic rights and duties in the Indonesian constitution are justiciable, even when judicial review might affect economic policy and public finances.

\section{Preamble}

The preambular "General Elucidation" to SJSN makes clear that the law is tied to the constitutional right to social security and to the constitutional duty to create a social security system. The General Elucidation also references international standards, noting that the Universal Declaration on Human Rights guarantees social security and that the International Labor Organization Convention $102^{181}$ asks states to provide a safety net for workers. ${ }^{182}$

After situating the law within the state's human rights obligations, the General Elucidation points out that existing policy has fallen short. The General Elucidation notes that existing social security programs "protect only a small portion of society. The majority of people have not been adequately protected. In addition the administration of these schemes has not been able to provide fair and adequate protection to participants according to program benefits which are their rights." 183 The General Elucidation also lays down principles to guide the development of the social security system. ${ }^{184}$ These include governance principles such as the "principle of transparency, prudence, accountability, efficiency and effectiveness" and financial principles stating that investment yields will be reinvested in social security funds and that funds themselves will be not-for-profit. ${ }^{185} \mathrm{~A}$ few principles

179. Id. at 118-21.

180. Id. at 124-5.

181. International Labour Organization, Convention Concerning Minimum Standards of Social Security, June 28, 1952, 35 I.L.C. No. 102.

182. Undang-Undang Republik Indonesia Nomor 40 Tahun 2004 Tentang Sistem Jaminan Sosial Nasional (Law of the Republic of Indonesia Number 40 Year 2004 About the National Social Security System) General Elucidation (Indon.) [hereinafter SJSN].

183. Id.

184. Id. General Elucidation, art. 4.

185. Id. General Elucidation. 
emphasize the universality of the social security system-the principle of portability clarifies that moving jobs or homes will not restrict access to social security, ${ }^{186}$ and the principle of compulsory participation states that "participation is mandatory for all people" but with the caveat that participation may be subject to "government economic affordability and program feasibility." 187 The principle of mutual assistance acknowledges the implications of compulsory participation for all Indonesians. It emphasizes that the new social security system is intended to "improve social justice for all Indonesian people," and therefore, "the able participants are to assist the less able in the form of compulsory membership for all people; the low risk participants are to assist the high risk; and the healthy participants are to assist the sick." 188

Thus, SJSN justifies what it is doing by reference to constitutional and international human rights, as well as the state's past inadequacies. Forward-looking principles emphasize social justice, even when this might impose duties on the more privileged to assist those who are less so. The law's (non-binding) rhetoric rests firmly in Indonesia's post-reformasi constitutional order, referencing a state that will be accountable to a community of rights-bearing individuals. SJSN's binding provisions, discussed below, are somewhat more ambiguous.

\section{Ambit of the Law}

All the different forms of social insurance introduced by SJSNhealth insurance, old-age savings, worker pensions, work-accident insurance, and death benefits-share certain features. Participation is compulsory, and each participant's contribution is a percentage of salary or a fixed nominal amount. ${ }^{189}$ The government will pay contributions for the "poor and underprivileged," who are deemed to be participants in the social security system. ${ }^{190}$

SJSN details who is covered by each particular type of social insurance. For example, each participant's health insurance can cover five family members, including adopted children and stepchildren. ${ }^{191}$ The average Indonesian household has 4.57 members, ${ }^{192}$ so the five-

186. Id.

187. Id.

188. Id. General Elucidation, II 10.

189. Id. art. 17.

190. Id. art. 1(5).

191. Id. General Explanations, $\S 20(2)$.

192. See Food AND Agric. ORg. Riga Project, Components of the INCOME AGGREGATE: "INDONESIA FAMILY LIFE SURVEY, WAVE 1" 1 (2008) (prepared for the Rural 
person limit seems designed to be comprehensive. To be entitled to a pension, individuals must contribute to the pension fund for fifteen years. ${ }^{193}$ If a working parent dies, surviving children receive the parent's pension until they marry or turn twenty-three. ${ }^{194}$ Dependent parents are also entitled to "inherit" pension benefits if an unmarried, working child dies, reflecting the Indonesian reality that many people are financially dependent on their children. ${ }^{195}$ In addition to factoring in a worker's dependents, SJSN also incorporates a buffer for those who lose their jobs-unemployed individuals can claim benefits for six months after being laid off, 196 at which point, if they are still unemployed and qualify as "underprivileged," the government steps in to pay their contributions. ${ }^{197}$ Work accident insurance is also clearly defined-it entitles beneficiaries to medical treatment and, if they die or are permanently disabled, to a cash payment. 198

However, while SJSN delineates who is covered by different types of social insurance, it leaves important decisions to the discretion of the executive. The government decides, and can change, how much of a burden social security places on individuals and employers in the present and how much protection it may offer in the future. Contribution rates are not laid down in the law; instead, the national government sets these "based on social and economic development and basic life necessities." 199 SJSN provides minimal, very loose guidance on making this crucial decision-for example, the government has to factor in the risk of the work environment when deciding contribution rates for work accident insurance. ${ }^{200}$ For worker pensions, not only does SJSN leave the contribution rates to the government, it does not specify retirement age either. ${ }^{201}$. Another fundamental decision left to the executive is defining who qualifies as "underprivileged" and "poor" and who is therefore entitled to have his or her social security contributions covered by the government. Further, while SJSN legislates into

Income Generating Activities Project), available at http:/www.fao.org/fileadmin/ templates/riga/docs/Country_survey_information/14_Indonesia93-Components_of_the_

Income_Aggregate.pdf.

193. SJSN art. 41(2).

194. Id. art. $41(1)(\mathrm{d})$.

195. Id. art. 41(1)(e). The age dependency ratio in Indonesia in 2010 was fifty-two-i.e., Indonesia had fifty-two dependents (people younger than fifteen or older than sixty four) per 100 persons in the working-age population. See Age Dependency Ratio, WoRLD BANK, http://data.worldbank.org/indicator/SP.POP.DPND (last visited Mar. 26, 2015).

196. SJSN art. 21(1).

197. Id. art. 21(2).

198. Id. art. 31(1).

199. Id. art. 17(3).

200. Id. art. 34(3).

201. Id. art. 39(4). 
existence a comprehensive "cradle to grave" social security system, it does not specify when the state must create and implement this system. Instead, SJSN allows programs to be rolled out progressively, first covering the formal sector and then the informal sector, ${ }^{202}$ and gives the President of Indonesia the authority to set the pace for this graduated implementation. ${ }^{203}$

\section{E. Entitlements and Obligations}

Thus, SJSN lays down what types of social security the national social security system will provide and whom each type of insurance will cover. How much of a benefit and burden each type of insurance entails is not specified, and neither is a timetable for setting up the social security system. On this analysis, SJSN imposes obligations on the Indonesian state but leaves the executive considerable leeway regarding how and when to fulfill those obligations and considerable control over defining the content of the obligations themselves. While the constitutional right to social security underpins SJSN, the law does not expressly recognize an overarching right to social security or disaggregated rights to the five distinct types of social insurance. Instead, it creates a few far narrower rights, which are discussed below.

SJSN grants participants in social security programs "the right to obtain ... information on the administration of the social security programs in which he or she participates."204 It further specifies that participants are entitled to information about the accumulated corpus of contributions, the rate of return on investments of their contribution, and the benefits payable through different programs. ${ }^{205}$ The government is required to disclose this information "at least once a year." 206 The BPJS law also includes providing information about social security programs to "participants and [the] public" as one of the core tasks of social security institutions. ${ }^{207}$

SJSN also establishes a right to compensation. It provides that participants in the health and work accident insurance programs are entitled to compensation if their "region does not have adequate health

202. Id. art. 13(1).

203. Id. art. 13(2).

204. Id. art. 16 .

205. Id. art. $49(3)$.

206. Id. art. 49(4).

207. Undang-Undang Republik Indonesia Nomor 24 Tahun 2011 Tentang Badan Penyelenggara Jaminan Sosial (Law of the Republic of Indonesia Number 24 Year 2011 About The Social Security Administrator) art. 10 (Indon.) [hereinafter BPJS]. 
facilities to meet [their] medical needs."208 However, the law does not set rates of compensation or require that compensation be commensurate with harm suffered as a result of deficient healthcare or sufficient to pay for private medical treatment. Rates and norms would prove difficult to define, since compensation under SJSN seems to arise in lieu of inadequate healthcare rather than delayed or withheld health insurance. SJSN's provisions on compensation imply a right to reasonably reliable, accessible healthcare. In fact, health infrastructure is highly variable in Indonesia and is undoubtedly below par in its more remote regions. If these legal provisions were interpreted generously, they could potentially lead to hundreds of thousands of claims for compensation, which suggests that the government will not only set low rates of compensation but also narrow down what health facilities are "adequate" in this regard.

The dispute resolution mechanism established by the BPJS law arguably creates an implicit right to a hearing. Institutions administering social insurance are required to establish a complaints resolution mechanism and must respond to any participant's complaint within five days. ${ }^{209}$ If the agency's response does not satisfy a participant, the participant can take his or her grievance into mediation. The BPJS law provides that the parties must mutually agree in writing on the mediator, ${ }^{210}$ which gives individuals somewhat more control than simply being funneled into an administrative forum. Either party can go to court if the dispute is not mediated to a resolution that each accepts. ${ }^{211}$

SJSN and the BPJS law together result in public law rights that mirror private contractual rights. Individuals have many of the rights they would have if they purchased private insurance. However, Indonesian residents have no choice about whether to participate in these programs; they must do so, as must private-sector employers. The BPJS law provides that participants have a duty to disclose information to national social security institutions; ${ }^{212}$ employers have a duty to register employees in the system ${ }^{213}$ and collect and pay social security contributions. ${ }^{214}$ BPJS commissioners can punish employers who evade these obligations with administrative sanctions, ${ }^{215}$ ranging from a mild

208. SJSN arts. 23(3), 32(3).

209. BPJS art. $48(1)-(2)$.

210. Id. art. $49(2)$.

211. Id. art. 50.

212. Id. art. 18.

213. Id. art. 15.

214. Id. art. 19.

215. Id. art. 17. 
measure-such as a written warning - to fines to denial of "certain public services"216 _ such as processing applications for business licenses and building permits. ${ }^{217}$ This last power, in particular, could prove an important tool in securing compliance from businesses.

Furthermore, the most basic right that participants have under each program-the right to, inter alia, health insurance or a pension per $s e$-is variable in scope because levels of contribution, service, and returns are determined by the government of the day. A subsidiary right such as the right to compensation is similarly variable because the government sets rates of compensation ${ }^{218}$ and might set these at a level that renders compensation entirely nominal. Thus, Indonesian residents have social security rights of uncertain content accompanied by nonnegotiable obligations to participate in social security programs and make the required social security contributions.

\section{F. Creating Institutions to Implement Social Insurance}

Clearly, SJSN is best viewed as a "framework law" setting definite endpoints-universal access to five types of social insurance-but not specifying how to reach those ends. It is not entirely ambiguous and lays down some surprisingly detailed rules (a five-day deadline for responding to individual complaints, for example). But on the whole, SJSN is a charter for future action, for progressive realization of the right to social security, guided by the principles it articulates. The many fundamental decisions still to be made are not ceded exclusively to the executive branch, however-SJSN stipulates future legislation on particular issues.

Adopting a framework law is a choice, but in this instance was also a necessity. As mentioned above, when drafting the law, the government did not properly calculate its fiscal consequences. Absent careful forecasting, it would have been risky to decide contribution or benefit rates, particularly for the defined benefit pensions included within SJSN. Moreover, Indonesia's public health infrastructure would not, in 2004 or even today, be able to deliver the medical care envisioned by SJSN. ${ }^{219}$ Even where infrastructure is robust, tracking beneficiaries would be difficult. At the time, the government had yet to identify people who could be categorized as poor and were therefore exempt from

216. Id. art. 17(2).

217. Id. Elucidation to art. 17(2).

218. SJSN art. 33.

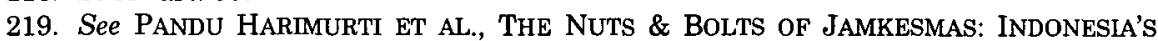
Government-Financed Health Coverage Program 17-20 (World Bank Universal Health Coverage Studies Series ed., 2013). 
making social security contributions. It also needed to identify and enroll informal sector workers who were not poor, create systems to ensure they were contributing regularly to social security funds, and set contribution rates that provide a safety net but do not discourage "formalization" of the economy. In a recent review, the World Bank stressed the need to develop regulations on investment and risk management and to guard against insolvency. ${ }^{220}$ All these tasks raise daunting questions of politics, logistics, design, and implementation.

SJSN was drafted and presented to the legislature by then President Megawati Sukarnoputri's government. In 2004, soon after SJSN was passed, Sukarnoputri, who leads the Partai Demokrasi Indonesia Perjuangan (PDIP), lost her mandate and was replaced by Susilo Bambang Yudhoyono, the leader of the Partai Demokrat. The "SBY" administration was not enthusiastic about tackling its predecessor's flagship legislation, not least because SJSN's aims might have seemed quixotic and certainly demanded the sort of marathon effort that does not dovetail well with a five-year electoral cycle. Even the preliminary task of estimating the fiscal implications of universalizing social security was a complex one. ${ }^{221}$

After SJSN was passed, there was a hiatus with little movement on the law's aims. SJSN gave the state five years to set up social security institutions and merge the state-owned enterprises administering existing social security programs into the new structure. ${ }^{222}$ The SBY administration missed this 2009 deadline, and the same year, a group of trade unions challenged the Indonesian government's failure to implement the system created by SJSN in the Jakarta district court. As this lawsuit made its way through the district court, PDIP members in the Indonesian House of Representatives began working with trade unions to draft a law giving content and institutional form to the social security system created by SJSN. ${ }^{223}$ In 2011, the district court ruled in the petitioners' favor, holding that the Indonesian government had to make progress on fulfilling its obligations under SJSN.224 The court's ruling was somewhat superfluous, as by this point the government had introduced its own law to set up social security institutions. However, campaigners for progress on SJSN's promises point out that the

220. See Policy Note on SJSN, supra note 158, at 3.

221. See interview with Dr. Suahasil Nazara, Professor, Univ. of Indon. Faculty of Econ., in Jakarta, Indon. (Aug. 27, 2013).

222. SJSN arts. 5(1), 52(2).

223. See interview with Surya Tjandra, Lecturer, Atma Jaya Catholic Univ., Member, Trade Union Rights Centre, in Jakarta, Indon. (Aug. 23, 2013).

224. See District Court of Central Jakarta Judgment No. 278/PDT.G/2010/PN.JKT.PST (July 13, 2011) (unofficial translation on file with the author). 
combination of litigation and political organizing pressured the incumbent government to draft its own law. ${ }^{225}$

Thus, in 2011 the law concerning the Social Security Administrative Body (Badan Penyelenggara Jaminan Sosial or "the BPJS law") was passed. ${ }^{226}$ The BPJS law's preambular General Elucidation avoids the high rhetoric of SJSN's preamble and notes straightforwardly that it is being passed following SJSN's instructions to create social security institutions. 227 The law creates two "social security administrative bodies," one to administer health insurance and the other to administer pensions and other forms of social insurance. ${ }^{228}$ It does not attempt to resolve any of the design and implementation dilemmas involved in universalizing social security. Instead, the BPJS law concentrates on who will implement these programs, how to choose senior administrators, and how to keep them honest.

As the social security system expands, the BPJS institutions will manage a lot of money. If ordinary Indonesians do not trust these institutions, they will try to evade the contributions to social security funds that are mandated by SJSN. Arifianto suggests that this might happen, arguing that the SJSN system is not just fiscally unfeasible but also that it neglects the best interests of individuals because it does not allow competition in social security provision. ${ }^{229}$ Exclusive state control over social security funds does not inspire confidence, given Indonesia's history of government graft, both mundane and spectacular. ${ }^{230}$ Therefore, it is crucial that social security institutions are subject to effective checks and balances. The Indonesian government guarantees social security funds, so if mismanagement led to funds becoming insolvent, the government would have to bear the resulting liability. As the World Bank points out, the government has a strong incentive to ensure that BPJS operations are clean, technically sound, and well supervised. 231

\section{Appointing the Right People and Holding Them Accountable}

The BPJS law makes both the social security institutions it establishes responsible to the President of Indonesia, ${ }^{232}$ who is advised

225. See interview with Surya Tjandra, supra note 223 .

226. BPJS \ 3.

227. Id. ๆ 4.

228. Id. arts. 5-6.

229. See Arifianto, supra note 152, at 65-67.

230. Id. at 68 .

231. See Policy Note on SJSN, supra note 158, at 3.

232. BPJS art. 7. 
by a council of social security experts. ${ }^{233}$ Each institution is to be managed by a board of directors and monitored by a board of commissioners. Directors and commissioners face a reasonably public selection process. The President of Indonesia forms a selection committee with members from both the government and the private sectors. ${ }^{234}$ The selection committee must publicize its choice of candidates and give the public at least five days to respond before recommending candidates to the President.235 The President appoints directors from among these candidates, ${ }^{236}$ while commissioners must be further approved by the legislature. ${ }^{237}$ The President also has wide powers to remove commissioners and directors on grounds ranging from incompetence, mismanagement, ${ }^{238}$ and criminality ${ }^{239}$ to the loose and malleable ground of "behaving abominably." 240

Once directors and commissioners take office, the BPJS law is very concerned with preventing conflicts of interest. Commissioners and directors cannot be connected to government bodies, businesses, or NGOs related to social security programs. ${ }^{241}$ Reflecting Indonesia's damaging experiences of nepotism under Suharto, the BPJS law stipulates that commissioners and directors cannot have "family ties to the third degree" with any of their counterparts. ${ }^{242}$ There are also injunctions against "decisions which contain elements of conflict of interest" 243 and "committing disgraceful acts." 244 However, while these restraints seem expansive, contravening these rules attracts only administrative sanctions from the President, which could include dismissal but can entail as little as a written warning. ${ }^{245}$ The BPJS law takes financial misdemeanors more seriously. It is an offense, punishable by a maximum of eight years in prison and a fine of IDR one billion, to doctor official records, misuse social security funds, report false information, transfer funds between different social security

233. The National Security Council or DJSN advises the President of Indonesia on social security policies and implementation. See id. art. 1(11).

234. Id. art. 28.

235. Id. art. $29(3)$.

236. Id. art. $30(1)$

237. Id. art. 30 .

238. Id. art. 34(c).

239. Id. arts. 33(b), 34(d).

240. Id. art. 34(e).

241. Id. art. 52(b), (f), (d).

242. Id. art. 52(a).

243. Id. art. 52(e).

244. Id. art. 52(c).

245. Id. art. 53. 
programs, or invest funds in financial instruments other than those expressly approved by the government. ${ }^{246}$

\section{Financial Management of Social Insurance Funds}

More important than the rules to prevent corruption by senior management are stringent norms on managing social security funds. The BPJS law puts in place some important measures in this regard. It specifies that the assets of social security funds-that primarily include participant contributions and interest from investing this corpus of money-must be scrupulously separated from other institutional assets. ${ }^{247}$ Social security fund assets can be used only for paying benefits, administering programs, and investing. ${ }^{248}$

Social security institutions are obligated to report annually to the President ${ }^{249}$ and to disclose their performance to the public through the media. ${ }^{250}$ Multiple public authorities, including the President's social security advisors, the national Financial Services Authority, and the State Financial Audit Board, can examine BPJS operations. ${ }^{251}$ However, the BPJS law does not build in periodic scrutiny by the legislature. Not only is the legislature left out of routine scrutiny of social security funds, it also has no role in authorizing special measures if these funds are in trouble. The government can act alone to formulate "special policies" to sustain social security programs if fiscal or monetary policy necessitates this and take "special actions" to protect programs in a financial crisis. ${ }^{252}$ The lack of legislative scrutiny is surprising, given that the Indonesian government's mismanagement and corruption amplified the effects of the Asian financial crisis. However, while the BPJS law exclusively empowers the Indonesian government to keep social security programs viable in the face of financial strain, it does not allow the government to dismantle social security institutions. The law specifies that these institutions "shall only be dissolved by law." 253

\footnotetext{
246. Id. art. 54 .

247. Id. art. 40 .

248. Id. art. $43(2)$.

249. Id. art. 37.

250. Id. art. $37(5)$.

251. Id. art. 39.

252. Id. art. 56(2)-(3).

253. Id. art. 46 .
} 


\section{Evaluating Social PRotection LaWs IN INDIA AND INDONESIA}

In Section I of this article, I noted that social and economic rights have proved difficult to enforce, and I argued that legislation could provide the scaffolding that enhances enforceability. I pointed out that a law can be used to define individual rights and state responsibilities, as well as to create mechanisms to reduce corruption and improve service delivery. I also suggested that legislating social and economic rights could make these rights more accessible to individuals, legitimize judicial enforcement, and embed these rights in the public sphere more firmly than policy alone. Below, I reflect on the extent to which the NFSA, SJSN, and the BPJS law achieve those aims.

\section{A. Tilting Toward Generality}

Public and commercial legislation in Indonesia is primarily in the civil law tradition, while Indian laws are designed for a common law legal system. We might expect legislation within the former mold to be thicker with detail, since civil law judges have less room to develop principles to fill statutory gaps and ambiguities than common law judges.

When comparing the NFSA with the Indonesian SJSN and BPJS laws, however, legal tradition does not correspond to the level of specificity in these laws. SJSN, in particular, is very much a framework law, which outlines the principles and design for social security programs but leaves the details to further implementing legislation and government regulations. The first such implementing legislation is the BPJS law, which creates institutions and stipulates how office holders will be appointed and regulated but does not engage with program design. The Indian NFSA, while laying down entitlements and obligations, also leaves much of the necessary detailing to state governments within India's federal political system. For example, the NFSA provides that social audits should be used to monitor the performance of the food distribution system but does not specify how often audits should take place.

The nature of what these laws are attempting makes it more convenient to be sparse on the specifics, regardless of the larger legislative tradition within which the law operates. An emphasis on principles, institutional mechanisms, and goals allows governments to adapt social protection laws to their capacities and might make these laws more politically palatable. It might also make social protection laws more flexible, so that the goals or baseline standards set by the law can operate alongside new and old policies. In fact, as discussed in 
Sections III and IV, all these laws quite substantially retain existing policies, expanding and adapting rather than discarding them.

\section{B. Tentative Rights}

\section{Substantive Rights: Weak and Expansive or Strong and Minimal}

If social protection laws veer toward abstraction and sparse detail, how does this affect the rights that such laws claim to protect and advance? Neither the NFSA nor Indonesia's social security legislation dwell on the overarching constitutional rights they seek to protect. SJSN and the BPJS law expressly reference the right to social security in the Constitution in the general elucidation to each law. The NFSA does not even mention the "right to food." All three laws focus on narrower substantive and procedural entitlements. The NFSA lays down what benefit individuals will receive, how much of that benefit they will receive, and which individuals are eligible to receive benefits. The substantive entitlement itself is a narrow one. Destitute Indians are entitled to, and the state is obligated to provide, food grain, rather than a nutritionally varied diet. SJSN lays down what types of social security individuals will receive, but neither SJSN nor the BPJS law defines contribution rates or other fundamental details.

The Indian NFSA is delivering a focused good to a slice of the population and slightly more expansive benefits to pregnant women and young children. It creates a strong, unambiguous right, but also one that is extremely spare. If we consider that the Act defines the state's minimum core obligations, it is adopting a minimal minimum and, by extension, a far thinner conception of the right to food than international norms point toward. The Act's limited vision might reflect a prudent, pragmatic assessment of state capacity and political will in the foreseeable future. At the same time, it could have incorporated more ambitious goals to be realized over the medium and longer term, but does not do so.

SJSN is creating a universal system of social security comprising multiple forms of insurance. The greater scope and complexity of the Indonesian project might explain why both SJSN and BPJS sidestep questions of quantity or quality of social insurance. SJSN avoids assigning immediately deliverable, minimum core duties to the state. It very much conceptualizes social security as a right to be progressively realized, thereby creating expansive but weak rights. In fact, SJSN cannot properly be viewed as creating immediately justiciable substantive rights. Rather, it creates the shell for future justiciability; 
further implementing laws and regulations are needed before social security rights are definite enough for individuals to claim.

\section{Procedural Rights: Limited Rights in Social Security and Food}

All the laws examined in this article create procedural rights. The NFSA and SJSN recognize the right to information about food and social security measures, and they place disclosure obligations on governments as well. India has a stand-alone law that strongly protects the right to information, ${ }^{254}$ but the NFSA particularizes this right in relation to food for the poor.

Both SJSN and the NFSA create what might loosely be described as rights related to a hearing, though neither squarely incorporates a right to a fair hearing. The NFSA gives individuals the right to file a grievance, while SJSN grants the right to file a complaint and receive a prompt response. Both laws create alternative dispute resolution mechanisms. SJSN requires that parties mediate disputes before going to court. The NFSA sets up a local, administrative complaints mechanism and allows appeals from the local grievance official to a quasi-judicial food commission in the state capital. SJSN and the BPJS law create clearer complaints mechanisms, and therefore clearer procedural rights, while the NFSA leaves the relationship between administrative and judicial dispute resolution unresolved. It is unlikely that food commissions, each of which will have a handful of commissioners, will have the capacity to hear more than a few appeals. Commissions might choose to concentrate primarily on complaints that highlight systemic flaws, leaving many appeals unheard.

These statutory procedural rights can usefully be conceptualized as rights in social security and food, as suggested by Odinkalu. ${ }^{255}$ These are rights that might make it easier or safer to access and use the benefit at issue but do not shape the size or content of the benefit. Courts are practiced at enforcing procedural rights of this sort, and they could do so without wading too far into policy design and budgetary considerations. Therefore, strong procedural rights should be incorporated into social protection laws. All the laws examined here

254. The Right to Information Act, No. 22 of 2005 (India).

255. See generally Chidi Anselm Odinkalu, The Impact of Economic and Social Rights in Nigeria: An Assessment of the Legal Framework for Implementing Education and Health as Human Rights, in COURTING SOCIAL JUSTICE: JUDICIAL ENFORCEMENT OF SOCIAL AND ECONOMIC RIGHTS IN THE DEVELOPING WORLD 183 (Varun Gauri \& Daniel M. Brinks eds., 2008) (discussing the implementation of the rights to education and health care in Nigeria in the context of both domestic and international law). 
miss this opportunity and are neither as comprehensive nor as coherent as they should have been in pinning down procedural entitlements.

\section{Non-Discrimination and Positive Measures}

Under international law, non-discrimination falls within a state's immediately binding, minimum core obligations in relation to social and economic rights. ${ }^{256}$ However, the right to freedom from discrimination is not protected in any of the laws analyzed in this article. Strictly speaking, specific non-discrimination statutory provisions are not necessary, given that Indians and Indonesians have a constitutional right to equality, which would certainly cover public service delivery. Nevertheless, particularizing the state's general obligation not to discriminate would have been beneficial. After all, the specific manifestation of a general right or obligation is not always obvious, not least to poorer rights holders. The NFSA and SJSN clarify what the right to information means in relation to food and social security respectively. It would have been useful to similarly set out what nondiscrimination means when administering food and social security entitlements in countries with diverse populations and diverse geographic terrains. Further, just as judges are well placed to enforce procedural fairness in relation to social and economic rights, they are similarly well suited to adjudicate non-discrimination claims. Harnessing this judicial expertise could have aided individuals from disadvantaged groups in both countries, but SJSN and the NFSA fail to do this.

While the NFSA does not place non-discrimination obligationsobligations to respect the right to equality - on public authorities, it does stipulate positive measures for women and children. The Act's provisions on women reflect a substantive understanding of gender inequalities, as well as a willingness to distill the lessons of past policies and political reform. Other vulnerable groups-for example, indigenous tribal communities-do not receive special measures, but the NFSA leaves state governments the option to provide greater protection for disadvantaged groups. By contrast, while SJSN commits the government to paying social security contributions for the poor, neither of the Indonesian laws acknowledges identity-based structural disadvantage in any way.

256. CESCR General Comment 20, supra note 112, ๆ 7; CESCR General Comment 3, supra note $30, \uparrow 1,5$. 


\section{Weak Remedies}

Legalizing social policy involves delineating individual rights and state obligations. Following from this, legalization-and legislation in particular-should also define the consequences of violating rights or defaulting on duties. This could include, inter alia, specific performance, monetary damages, and punitive measures. It might even include requiring the state to act against third parties who are disrupting access to social protection. A key aspect of legalization is that the coercive powers of courts can be brought to bear when individuals are denied social protection rights. However, both the Indian and the Indonesian laws dull the coercive potential of courts. These laws lack clear provisions on different types of remedies. They also delay access to courts.

Under the NFSA, individuals are entitled to a cash allowance if they do not receive grain, but this provision does not actually cover the situation where an individual's entitlement-whether food or cash-inlieu-is withheld or unreasonably delayed. SJSN grants individuals a right to compensation but fails to clarify when this right comes into play, and whether individuals are entitled to compensation when they receive poor healthcare or when they cannot access health insurance. Both laws leave rates of compensation or cash-in-lieu to be decided by the government.

None of these laws establishes punishments for officials who have been remiss, despite a long experience of corrupt public services in both countries. Compensation from the public purse is unlikely to shift the incentives of individual grassroots officials who might be corrupt or negligent, in the way that the prospect of individual punishment would. While no repercussions are stipulated for government officials, social security institutions have the power under SJSN to punish privatesector employers who do not fulfill their legal obligations. This punitive power against third parties might assist an individual whose employer is evading contributions on his behalf.

As far as specific performance is concerned, the NFSA allocates relatively weak remedial powers to the administrative mechanisms it sets up. At the local government level, the designated grievance officer would be able to direct junior officials on what to do, but not officials who outrank the grievance officer. Food commissions cannot issue binding orders to state governments; they can only recommend what to do in response to individual complaints as well as systemic problems. The mediation mechanism set up by SJSN gives individuals more control over defining binding outcomes, at least at a formal level; in practice, a person who is underprivileged might hesitate to assert 
preferences when resolving a dispute against an employer or public authority.

Once individuals have traversed alternative mechanisms, they can approach the courts. While judicial power to compensate and punish is limited, judges can order government officials to fulfill statutory duties. Such orders-public, embarrassing, and carrying the potential for judicial punishment if flouted-might prove to be an important disciplining force.

\section{Mechanisms to Aid Accountability}

Given the levels of public-sector corruption in India and Indonesia, empowering individuals to enforce their due is one of the crucial functions socioeconomic rights legislation should play. However, the burden of making governments fulfill social protection duties should not be left only to individuals. Asymmetries of information, resources, and power mean that individuals can rarely trigger systemic improvements. Therefore, it is important that all the laws examined in this article also incorporate other rules and mechanisms to hold governments accountable.

As discussed in Section III, the NFSA requires social audits at the local level. It also sets up a hybrid watchdog institution to hear individual complaints and investigate government performance of its own accord as well as advise governments on policy. State governments finance food commissions, which compromises the independence of these institutions. That said, food commissions incorporate elements of the "weak-form" dialogic judicial review that is advocated by scholars like Tushnet and Dixon for social and economic rights. ${ }^{257}$ Food commissions cannot issue binding orders, but they can persuade and embarrass governments. They can investigate and publicize serious violations of the right to food, moderate conversations between governments and civil society, and communicate good practice. They operate alongside courts and could even work in tandem with courts on occasion-for example, by monitoring whether the government is complying with court orders.

In Indonesia, the BPJS law sets up two new entities responsible for implementing the goals laid down in SJSN. These entities have enormous responsibility and power, and therefore, it is not surprising that the BPJS law devotes attention to how senior personnel will be appointed and regulated. While neither law prescribes penalties for grassroots official corruption, the BPJS law lays down consequences for wrongdoing by the directors and commissioners of social security

257. See TUSHNET, supra note 21; Dixon, supra note 36 . 
institutions. The existing provisions are important, given the financial risk to which corruption could expose individual beneficiaries. They are also necessary if the new social security institutions are to garner public legitimacy, given the long half-life of Suharto-era nepotism. However, these provisions could go further and be smarter. Rules to ensure sound financial management needs to be much more detailed, and this statutory gap should be filled by government regulation or a new law. In another regrettable omission, the BPJS law builds legislative scrutiny into appointing senior personnel but not into monitoring their performance thereafter.

In both India and Indonesia, social protection laws can improve public services compromised by entrenched corruption. Both judicial scrutiny and the obligation to disclose information aid accountability. All the laws examined here establish a number of other accountability mechanisms as well. Thus, government performance will be monitored by existing institutions-the Financial Services Authority in Indonesia, for example-and by specialized bodies-such as the food commissions under the NFSA or the President's expert advisory council under SJSN. The NFSA's provisions are more innovative and more attentive to grassroots accountability. However, accountability mechanisms that rely primarily on administrative scrutiny are unlikely to be as robust as those that incorporate regular scrutiny by the legislature as well as judicial review. In this regard, the BPJS law establishes stronger accountability measures than the Indian NFSA, but both laws could have worked more with the grain of democratic political competition to build stronger monitoring mechanisms.

\section{E. Bringing Rights Within Reach}

Both SJSN and the NFSA create alternatives to conventional courts whose practical repercussions are difficult to gauge without conducting socio-legal research once these mechanisms have bedded down over the next few years. However, we can evaluate at this stage whether the laws create a facilitative framework for enforcing rights. On the one hand, mediation in Indonesia and administrative forums in India delay access to courts. On the other hand, these alternative mechanisms, because they are relatively close at hand, might motivate people to complain when deprived of an entitlement. In India, it is certainly the case that litigation tends to be lengthy, opaque, and distressing - the more so for those who are poor, as legal aid is difficult to obtain. Even though administrative remedies are weaker than judicial ones, it is probable that more people will use a local administrative mechanism than would opt to litigate. 
While not a first resort, courts remain a later resort under both the NFSA and SJSN. Since these laws clearly authorize judicial intervention, it is likely that courts will feel free to respond vigorously to official wrongdoing and delay, particularly where procedural rights are at issue. In India, individuals will also find it easier to articulate their claims, since these will flow from the concrete, relatively modest terms of the NFSA rather than from the abstract terms of constitutional rights. This would also be the case in Indonesia once entitlements under SJSN are anchored by specific details, whether through government regulations or additional legislation.

Of course, small social protection claims will not yield the sort of principles developed by some of the celebrated, controversial judicial decisions on social and economic rights in jurisdictions like India and South Africa. However, the experience of litigation based on socioeconomic rights legislation in Brazil indicates that court decisions in small claims cases can influence government behavior. ${ }^{258} \mathrm{As}$ a corpus of judgments on particular issues develops, principles emerge incrementally through repetition, influencing policy content and implementation.

In Indonesia, given that the social security system is going to be universal, it is highly likely that the middle classes will litigate more than the poor. There is, therefore, the danger that any policy shifts that accrue as a result might reflect middle-class interests to the neglect or even the detriment of the poor. Particularly for those who are marginalized, it is important to preserve the option of class action and public interest litigation before the higher judiciary alongside individual claims in lower courts.

It is fortunate that none of the laws discussed here reduce space for such litigation. In the past, Indian courts have ordered governments to follow through on pre-existing policies, and the Indonesian Constitutional Court has ordered the executive branch to fulfill constitutional obligations related to social and economic rights. Judges in both jurisdictions can still function as enforcement mechanisms, but they will be on firmer ground since they are enforcing legislation-a higher commitment than policy and a more detailed one than a constitutional provision on its own. If state governments in India are falling short of the NFSA's requirements, the Indian Supreme Court can still use remedies such as "continuing mandamus"-periodic hearings where governments report on progress. In both jurisdictions, public

258. See Florian F. Hoffmann \& Fernando R. N. M. Bentes, Accountability for Social and Economic Rights in Brazil, in COURTING SOCLAL JUSTICE: JUDICIAL ENFORCEMENT OF Social AND Economic Rights in the Developing WoRlD 100, 136-38 (Varun Gauri \& Daniel M. Brinks eds., 2008). 
interest litigation can still provide a platform for civil society groups and governments to argue as well as negotiate with one another. Since SJSN is a framework law, the results of judicial review could iteratively be fed into future government regulations. Thus, despite several weaknesses, these social protection laws can assuage fears about judicial overreach during rarefied, occasional "impact litigation," while also facilitating more mundane justiciability.

\section{F. Stabilizing Social and Economic Rights}

As noted above, whether these laws fulfill their potential to ease rights enforcement and to legitimize and structure judicial intervention can properly be evaluated only after a few years. Similarly, it is difficult to ascertain this early whether the NFSA is a stable vehicle for the right to food in India. In Indonesia, however, it is evident that the SJSN, once in force, has proved to be quite "sticky" and has given the right to social security a firmer foothold than policy alone would have given.

SJSN may have been passed during a unique time in Indonesia's history, but its presence shifted the terms of politics-as-usual in the years that followed. Despite the SBY administration's ambivalence about SJSN, the Indonesian government chose to simply neglect the law rather than repeal or amend it. At the same time, the existence of a law helped civil society groups to lobby the government and mount a legal challenge. It was no small thing for the Jakarta district court to order the Indonesian government to press forward with SJSN's lofty promises. The court would not have been able to do so without a law that, firstly, authorized judicial intervention and, secondly, gave the government a deadline for establishing social security institutions. SJSN legitimized a judicial role in protecting the right to social security, and served as a means for civil society to nudge the government. This legislation may not have been the only means to lobby the state, but it was a potent one. Eventually, the BPJS law emerged from a process of bipartisan debate and negotiation in the Indonesian legislature. Providing social security for all Indonesians may progress by inches, but SJSN has made it hard to abandon this difficult endeavor.

In India, the NFSA's fate is currently less certain. When the Indian government proposed the NFSA, the left-leaning United Progressive Alliance (UPA) coalition was in power. As mentioned in Section III, the draft law divided civil society and was heavily criticized by many policy experts. Despite this strong criticism, the Act eventually passed after a six-hour debate in the lower house of the Indian Parliament and a tenhour debate in the upper house. While largely incorporating pre-existing policies and infrastructure, the NFSA also included provisions to 
appease market-oriented critics, such as allowing governments to substitute cash allowances for food-grain. Half a year later, when the avowedly pro-market National Democratic Alliance (NDA) took power in New Delhi, it declared the NFSA excessively expensive and initiated a review of the Act. ${ }^{259}$ The government has since proposed to reduce the number of people entitled to food-grain under the NFSA in the short term and to make more thoroughgoing changes in the longer term. ${ }^{260}$ These proposals have a strong element of political point scoring. The NDA prioritized reviewing the previous government's flagship law over other compelling policy questions, and the proposed reforms contradict the NDA's earlier arguments, while it formed the Parliamentary opposition, that the law was not generous enough. 261 Whatever the merits of different policy positions, it is unlikely in this political context that any future amendments will be drastic. The public nature of the debate currently unfolding 262 and negotiation within Parliament will make it politically difficult to revoke food entitlements for the poor, although it is possible that the content of these entitlements might shift.

\section{CONCLUSION}

The Universal Declaration of Human Rights may have recognized social and economic rights on the same terms as civil and political rights in 1948, but states have been slow to convert these rights from moral claims to enforceable legal entitlements. In fairness, doing so is not easy. Neither broadly drafted constitutional provisions nor international legal standards give much guidance on how to make the budgetary, distributive, and design decisions involved in implementing

259. See Nitin Sethi, Reforming FCI or cutting back food security?, BÜS. STANDARD (Jan. 29, 2015), http://www.business-standard.com/article/economy-policy/reforming-fci-or-cuttingback-food-security-115012901297_1.html.

260. See id.

261. See id.; Press Trust of India, Food Security Act: BJP Wanted to Oppose but Feared Backlash, IBN LIVE (Jan. 22, 2015, 07:46 PM), http://ibnlive.in.com/news/food-securityact-bjp-wanted-to-oppose-but-feared-backlash/524358-37-64.html.

262. For a positive view of the proposed reforms, see Ajay Chhibber, A New Menu, INDIAN EXPRESS (Feb. 9, 2015, 12;14 AM), http://indianexpress.com/article/opinion/ columns/a-new-menu-2/; for a skeptical view, see Shambhu Ghatak, Shanta Kumar Committee Report: Is This Committee Overestimating Leakages in Ration to Curb the Food Security Act? INDIA TOGETHER (Feb. 13, 2015), http://indiatogether.org/shanta-kumarcommittee-report-on-pds-leakage-and-food-security-act-government; for the view of the political party leading the Parliamentary opposition, see Press Trust of India, Congress Flays BJP Government on Suggestion to Cut in Food Security Act Coverage, ECON. TIMES (Jan. 24, 2015, 06:53 PM), http://articles.economictimes.indiatimes.com/2015-01-24/news/ 58408184_1_food-security-act-party-spokesman-randeep-surjewala-bjp. 
socioeconomic rights. ${ }^{263}$ Nevertheless, many states have been forced to grapple more fully with these rights over the past two decades. Constitutional recognition led to judicial review based on social and economic rights in some countries. More recently, a few states have attempted to legislate enforceable social and economic rights. In assessing India and Indonesia's efforts in this regard, it is worth remembering that these states had relatively few templates to learn from.

Even with that caveat, the Indian NFSA and Indonesian laws on social security are quite disappointing. They are partial and tentative in particularizing substantive rights and recognizing procedural ones. This failing, while understandable when we contextualize each law, hollows the strengths these laws have. That said, the accountability mechanisms and remedies these laws establish, despite some regrettable omissions, will push the state to improve its performance and enable individuals to enforce their rights more easily.

For all their flaws, these laws exemplify and will further stimulate the mutually reinforcing relationship between constitutionalizing, litigating, and legislating social and economic rights. Constitutionalization of social and economic rights fostered judicial review in both India and Indonesia. In India, the evident limits of judicial review triggered demands for legislation to protect these rights; in Indonesia, a new constitutional order inspired the state to proffer such legislation. The resulting laws, in turn, enmesh the judiciary more thoroughly in enforcing social and economic rights. These developments may be slow and sometimes acrimonious, but they pressure the state to do better, to treat progressive realization of social and economic rights as a commitment rather than as a euphemism for inaction.

In Section I, I noted the observation by Sen and Drèze that democratic governments since the twentieth century have averted famines because they fear the retribution that would follow if they ignored large numbers of their citizens in acute distress. However, as those authors argue, this is only a small part of the historical picture. While democratic governments in developing countries respond quickly to extreme, headline-grabbing events, they have been far less effective at eradicating chronic deprivation. The latter endeavor requires the sort

263. On the limits of international legal norms, see generally Christine Chinkin, Health and Human Rights, 120 PUB. HEALTH 52 (2006) (arguing that human rights provide both an alternative and a complementary language for discussing health care issues). On the limits of socio-economic rights in general in this regard, see generally Varun Gauri, Social Rights and Economics: Claims to Health Care and Eduction in Developing Countries (Policy Research Working Paper 3006, 2003) (analyzing contemporary rights-based and economic approaches to health care and education in developing countries). 
of routine, steady service delivery and governance that electoral politics does not adequately incentivize. In countries like India and Indonesia, supplementing the traditional checks and balances of democracy with more specialized, accessible mechanisms to monitor the state will help provide much needed incentives. The ethical and economic case for developing such mechanisms could not be stronger-poverty disfigures and shortens the lives of millions in both countries. Legislation on social and economic rights, which allows us to deploy legal tools and technologies to address deprivation, is one such democracy-deepening commitment device. As such, the laws discussed in this article are political and legal experiments that should be welcomed despite their weaknesses. There are important lessons to be learned from the future trajectory, impact, and failings of India's NFSA and Indonesia's laws on social security. 